\title{
Ciudad y territorio, ortodoxia y disidencia reli- giosa en el Imperio romano cristiano (siglos IV-V) ${ }^{1}$
}

\author{
Raúl ViLlegas Marín \\ Laboratoire d'études sur les monothéismes (UMR 8584) \\ Grup de Recerques en Antiguitat Tardana. Universitat de Barcelona \\ rvillegasmarin@gmail.com
}

\section{RESUMEN}

Tras una introducción en la que se presentan algunas aproximaciones sociológicas al estudio del fenómeno de la lenta cristianización del campo romano -en comparación con la de los ámbitos urbanosse estudia la incidencia en este fenómeno de las tensiones y conflictos de poder entre los principales agentes de la cristianización del Imperio: autoridad imperial, jerarquías eclesiásticas, homines sancti carismáticos situados en los límites de la Iglesia institucional y grandes propietarios rurales. Tales tensiones adoptaron en ocasiones la forma de un conflicto entre "ortodoxia" y "heterodoxia religiosa". Hacia principios del siglo $\mathrm{V}$ se ha forjado una geografía simbólica en la que la ciudad es la fortaleza de la ortodoxia cristiana y el campo el ámbito privilegiado de la disidencia religiosa.

Palabras clave: Cristianización. Campo. Paganismo. Ortodoxia. Herejía. Hombres santos. Jerarquía eclesiástica. Grandes terratenientes. Ascetismo aristocrático. Códice Teodosiano.

\section{Town and Countryside, Orthodoxy and Religious Dissent in the Christian Roman Empire (IV-V Centuries)}

\begin{abstract}
After a short introduction to some sociological explanations of the slow Christianization of Roman countryside -as compared to that of urban centers- it is studied how this process was affected by power conflicts between the main agents involved in it: the imperial authorities, ecclesiastical hierarchies, charismatic "holy men" often outside the institutional church and great Christian landlords. Such conflicts took sometimes the appearance of a clash between orthodoxy and heterodoxy. By the early Fifth Century, we find the development of a symbolic geography in which the city is seen as the fortress of Christian orthodoxy, unlike the countryside where religious dissent finds refuge.
\end{abstract}

Key words: Christianization. Countryside. Paganism. Orthodoxy. Heresy. Holy men. Ecclesiastical hierarchy. Landlords. Aristocratic asceticism. Theodosian Code.

Sumario: 1. Introducción: kérygma cristiano y "religiosidad rural". 2. Legislación imperial antipagana y patronazgo urbano y rural. 3. El ascetismo aristocrático cristiano in rure y la expansión del cristianismo. 4. Disidencia cristiana y grandes dominios rurales. 5. Conclusiones.

1 Este estudio ha sido realizado gracias a la obtención de una ayuda postdoctoral Beatriu de Pinós (2009 BP-A 00225), concedida por el Comissionat per a Universitats i Recerca del Departament d'Innovació, Universitats $i$ Empresa de la Generalitat de Catalunya, y se enmarca en el proyecto de investigación HAR201015183, cuyo investigador principal es el Dr. Josep Vilella Masana. 


\section{INTRODUCCIÓN: KÉRYGMA CRISTIANOY "RELIGIOSIDAD RURAL"}

Es de sobra conocido que la expansión del cristianismo en las zonas rurales del Imperio romano fue un proceso notablemente más lento que la cristianización de las ciudades. Este hecho no escapó a los pensadores cristianos contemporáneos. Ciertamente, a principios del siglo $\mathrm{V}$ la legislación antipagana de los emperadores de la dinastía teodosiana da lugar a la aparición de un discurso apologético cristiano que proclama la total derrota de los paganismos, ${ }^{2}$ lo que distaba mucho de responder a una realidad objetiva incluso en el caso de las ciudades donde residía la intelligentsia cristiana forjadora de este discurso. Los documentos oficiales de la corte imperial no fueron impermeables a esta abusiva retórica triunfalista, expresión de un voluntarismo ajeno a la realidad: paganos qui supersunt, quamquam iam nullos esse credamus... Esta sentencia se halla en el extracto de una constitución del cristianísimo emperador Teodosio II preservado en el Codex Theodosianus. ${ }^{3}$ Se trata del mismo emperador que, quince años más tarde, volverá a legislar contra los paganos que seguían practicando los nefarii sacrificiorum ritus en la clandestinidad, ${ }^{4}$ a cuya impiedad el monarca culpaba de una distorsión de las leyes de las estaciones que habría acarreado un año de malas cosechas, castigo divino -así la constitución- de la recalcitrante impiedad pagana de algunos habitantes del Imperio. Éstos debían ser ofrecidos a Dios como víctimas expiatorias por la autoridad imperial. ${ }^{5}$

Esta cristianización "a doble velocidad" del mundo antiguo -calificativo aquel que empleamos no sin simplificar quizás más de lo apropiado $-{ }^{6}$ puede sin duda explicarse

2 Así, el autor del Carmen de prouidentia Dei, por ejemplo, insinúa que en la Galia de finales del año 426 el culto a las viejas divinidades paganas no es ya sino un recuerdo del pasado. Vide Carmen de prou. Dei, vv. 765-768, ed. VILlEGas Marín 2010, 124: ille per innumeros uultus et mille per aras / barbatos leuesque deos, iuuenesque senesque / ut quondam fecere, colens, iam errore parentum / abiecto solum Vnigenam summissus adorat. Respecto al ámbito geográfico de composición y a la cronología de esta obra, me permito remitir a mi introducción a la citada edición, páginas 47-55.

3 Cod. Theod. 16, 10, 22 (9 de abril de 423), ed. Mommsen [en] Mommsen - Meyer 1905, 904.

4 Nou. Theod. II, 3 (31 de enero de 438), ed. Meyer [en] Mommsen - Meyer 1905, 7-11, aquí 9: hinc perspicit nostra clementia paganorum quoque et gentilis inmanitatis uigiliam nos debere sortiri, qui naturali uesania et licentia pertinaci uerae religionis tramite discedentes nefarios sacrificiorum ritus et funestae superstitionis errores occultis exercere quodammodo soliditudinibus dedignantur. Respecto a la pervivencia de los sacrificios paganos durante el reinado de Teodosio II cf., por ejemplo, el testimonio de Calínico, quien nos habla de una villa (oĩ

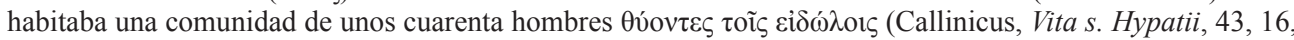
ed. BARTELINK 1971, 260).

5 Nou. Theod. II, 3, Meyer [en] Mommsen - Meyer 1905, 10: oportet enim dare nos hanc uictimam meliorem ara Christianitatis intacta seruata. An diutius perferemus mutari temporum uices irata caeli temperie, quae paganorum exacerbata perfidia nescit naturae libramenta seruare? Vnde enim uer solitam gratiam abiurauit? unde aestas messe ieiuna laboriosum agricolam in spe destituit aristarum? unde hiemis intemperata ferocitas ubertatem terrarum penetrabili frigore sterilitatis laesione damnauit? nisi quod ad inpietatis uindictam transit legis suae natura decretum. Quod ne posthac sustinere cogamur, pacifica ultione, ut diximus, pianda est superni numinis ueneranda maiestas. Recuérdese Tertullianus, Apol., 40, 2, ed. DeKKers 1954, 85-171, aquí 153: si Tiberis ascendit in moenia, si Nilus non ascendit in rura, si caelum stetit, si terra mouit, si fames, si lues, statim "Christianos ad leonem!".

6 En efecto, la dualidad "ciudad-campo" no da suficiente cuenta de la enorme diversidad de "ritmos de cristianización" en las zonas urbanas y rurales del Imperio romano durante las primeras cuatro centurias de la era cristiana. Es sabido, por citar tan sólo un ejemplo, que el movimiento montanista, surgido en Frigia en 
por una amplia pluralidad de factores. De acuerdo con Max Weber, por ejemplo, los estratos campesinos de las sociedades preindustriales se habrían mostrado siempre bastante impermeables a algunas nociones fundamentales del kérygma cristiano, tales como las de "pecado" o "salvación": el "campesino-tipo" weberiano no habría sentido nunca la necesidad de "ser salvado". Siendo así que su actividad económica dependía estrechamente de fenómenos naturales cuyas leyes no comprendía, sus prácticas religiosas se orientarían esencialmente al dominio (o a crear una ilusión de dominio) de tales fuerzas de la naturaleza. ${ }^{7}$ Cierto es que las narraciones sobre las actividades de misioneros cristianos en las zonas rurales de la Antigüedad tardía o de la Alta edad media son ricas en episodios milagrosos en los que tales misioneros -generalmente monjes- son representados como "señores de las fuerzas de la naturaleza", capaces de dar respuesta a las preocupaciones más inmediatas de los campesinos que debían ser "convertidos" a la fe cristiana. Como ejemplo de ello pueden citarse distintas historias relativas a la actividad evangelizadora de Martín de Tours entre algunas comunidades campesinas de la Galia. En el uicus de Amboise, por ejemplo, Martín habría destruido un templo pagano mediante una violenta tormenta, obtenida de Dios gracias a sus oraciones. ${ }^{8}$ El episodio nos muestra a Martín actuando como un tempestarius, aquellos individuos a los que los campesinos reconocían la capacidad - de incalculable valor- de provocar o evitar tormentas a su arbitrio y contra quienes todavía escribe Agobardo de Lyon -s. IX-su Liber contra insulsam uulgi opinionem de grandine et tonitruis. ${ }^{9}$ De hecho, en las historias recogidas por su biógrafo Sulpicio Severo ni una sola de las conversiones de campesinos paganos supuestamente provocadas por las actividades de Martín es presentada como el resultado de la predicación del kérygma cristiano: tales conversiones, entusiásticas y más o menos masivas, suceden siempre a un hecho milagroso que revela la capacidad de Martín de interferir en el orden natural. ${ }^{10}$

el último cuarto del siglo II, aun sin ser un fenómeno exclusivamente rural, arraigó de modo especial entre la población campesina del valle del Tembris (en el norte frigio). Vide, a este respecto Frend 1979, en especial 35-36, quien -quizás de un modo demasiado esquemático- subraya la existencia de una serie de elementos propios de los movimientos cristianos de base rural (carácter profético y carismático, tensión escatológica, ethos martirial), en oposición al cristianismo urbano.

7 Vide, por ejemplo, WeBER 1996, 241-328 (traducción francesa del capítulo XI de la parte III de M. Weber, Wirtschaft und Gesellschaft), en especial 275-276.

8 Sulpicius Seu., Gallus siue Dial. 3, 8, 4-7, ed. Fontaine 2006, 318-320. El hombre santo cristiano no obra milagros en virtud de un poder que le sea propio, sino que obtiene de Dios su intervención sobrenatural en el mundo en cuanto, por la integridad de su vida y por su respeto a los mandatos divinos, se ha hecho digno de ser escuchado por la divinidad: sobre este punto insistirán particularmente las biografías de los homines sancti de esta época (uide, por ejemplo, el explícito inciso en este sentido de Callinicus, Vita s. Hypatii, 47, 7-9, BARTELINK 1971, 274).

9 Cf. Giordano 1983, 101.

10 Vide, por ejemplo, Sulpicius Seu., Vita Mart., 13, ed. FontaINE 1967, 280-282: tras haber destruido un templo pagano en un burgo, Martín se dispone a abatir un pino - probablemente consagrado al culto de Cibeles, cf. el excepcional comentario de este pasaje por FonTAINE 1968, 737-766-. El sacerdote local y otros fieles metróacos se oponen al furor antipagano del santo y le desafían, ofreciéndose a ser ellos mismos quienes abatan el árbol si Martín, por su parte, acepta ponerse debajo de él, exponiéndose de este modo a ser aplastado por su caída. Martín consiente a ello: cuando el árbol se abate sobre él, el santo realiza en el aire el signo de la cruz, lo que suscita un violento golpe de viento que cambia la dirección de la caída del pino y le salva la vida. Las masas gentiles, ante el milagro, reclaman unánimemente que el santo les imponga las manos (es 
Ejemplos paralelos podrían hallarse en prácticamente todas las regiones del Imperio: en las cercanías de Gamala, en Siria, el monje Thalélaios habría convertido a los campesinos de la zona realizando diversos prodigios en beneficio no sólo de los hombres, sino también de sus camellos, de sus asnos o de sus mulas; ${ }^{11}$ en este mismo sentido, los aldeanos de las cercanías del monasterio de Rufiniana (Calcedonia) acudían a su fundador y abad, Hipacio, con sus animales enfermos, los cuales eran sanados por la intercesión del hombre santo. ${ }^{12}$ El monje que consiguió hacerse reconocer por los campesinos una autoridad carismática devino frecuentemente no sólo un mediador entre aquéllos y las fuerzas de la naturaleza regidas por Dios, sino

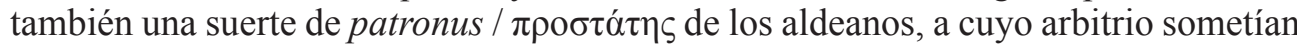
sus querellas y quien en ocasiones actuaba como su defensor ante los representantes o los depositarios del poder civil y económico (las autoridades civiles, los exactores de impuestos, los grandes propietarios, etc.). ${ }^{13}$

Poco puede sorprender, en todo caso, que los campesinos convertidos al cristianismo por estos hombres santos ${ }^{14}$ cuya imagen se asemejaba tanto a la de los vie-

decir, el ingreso en el orden de los catecúmenos cristianos). Cf. igualmente Id., Vita Mart., 14, 3-7, FonTAINE 1967, 284: Martín se dispone a destruir un templo pagano en Levroux, pero los gentiles se oponen a ello y consiguen expulsarle. El santo se retira a un lugar cercano y durante tres días seguidos se entrega a ayunos y oraciones; recibe entonces la visita de dos ángeles armados de picas y escudos, quienes le dicen que han sido enviados para protegerle y evitar que nadie se oponga a su campaña contra el paganismo. Animado por ello, Martín reemprende la destrucción del templo, ahora ante la total inacción de los campesinos paganos. Éstos comprenden entonces que el poder divino les ha "paralizado" e impedido oponerse a la acción de Martín, proclamando a gritos la necesidad tanto de adorar "al Dios de Martín" (deus Martini colendus) -remarcable expresión, que parece traducir una suerte de natural y espontánea conversión no tanto al monoteísmo como a un henoteísmo cristiano- como de abandonar a los ídolos, que se han revelado incapaces de defenderse ante el santo cristiano. Y ver asimismo Id., Gallus siue Dial. 2, 4, 4-9, Fontaine 2006, 234-236: Martín predica a los habitantes paganos de un uicus de los alrededores de Chartres. Durante la prédica, una mujer se acerca con su hijo recientemente fallecido y le pide que le devuelva la vida. Martín, efectivamente, resucita al niño, tras lo cual la multitud pagana pasa a confesar a Cristo. El santo impone las manos a los nuevos creyentes, consagrándolos catecúmenos.

11 Theodoretus Cyr., Hist. relig., 28, 5, ed. CANIVET 1977-1979, t. II, 230.

12 Callinicus, Vita s. Hypatii, 22, 21, Bartelink 1971, 144.

13 Cf., por ejemplo, Id., Vita s. Hypatii, 6, BARTELINK 1971, 92-94: el monje Jonás intercede ante Rufino y otros illustri de Constantinopla en beneficio de los campesinos de las cercanías de su monasterio, afligidos por una hambruna -consecuencia de las razzias godas sobre Tracia en 395-; Theodoretus Cyr., Hist. relig., 17 , 3-4, CANIVET 1977-1979, t. II, 36-40: Abrahames media entre unos implacables recaudadores de impuestos y los campesinos libres que habitan en una pequeña aldea del Líbano, tras lo cual éstos le piden que acepte ser su

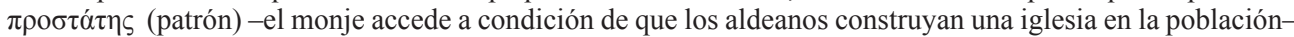
(y cf. además, como otro testimonio de denuncia de la violencia de los exactores de impuestos en la literatura hagiográfica, el episodio de Martín de Tours apaleado por un grupo de soldados en misión fiscal, agresión a la que el santo habría respondido paralizando los caballos que aquéllos montaban [Sulpicius Seu., Gallus siue Dial. 2, 3, FonTAINE 2006, 226-230]: la crítica ciertamente no va más allá, pero considérese también, en similar sentido, la aguda denuncia de la injusticia del sistema fiscal romano en el De gubernatione Dei del monje y presbítero Salviano de Marsella, Saluianus Mass., De gub. Dei 4, 6, 30-31, ed. Lagarrigue 1975, 254-256; Id., De gub. Dei 5, 4, 17-18, Lagarrigue 1975, 322-324, entre otros pasajes); Theodoretus Cyr., Hist. relig., 14, 4, CANIVET 1977-1979, t. II, 14: el monje y presbítero rural Maesymas intercede a favor de unos colonos ante su patrón Létoios -uno de los principales de la curia de Antioquía-, quien les reclamaba sus rentas con un exceso de rigor.

14 El lector habrá percibido en estas líneas algunos rasgos de la definición del homo sanctus "ideal-típico" tardoantiguo, forjada por P. Brown en un artículo que señaló un hito en la historiografía de la Antigüedad tardía: Brown 1971. Conviene en todo caso no perder de vista que Brown construyó su arquetipo de homo 
jos tempestarii o a la de chamanes de todo tipo -y que a menudo deambulaban por los límites, tampoco demasiado nítidos, de la ortodoxia salvaguardada por la Iglesia institucional- ${ }^{15}$ no creyeran necesario renunciar a aquellas prácticas de estricta raíz pagana -ni a sus practicantes- orientadas igualmente a ejercer un dominio sobre los poderes de la naturaleza, hecho este sobradamente atestiguado -por ejemplo- por los sermones de Cesáreo de Arlés o por el De correctione rusticorum de Martín de Braga para la Galia y la Hispania sueva del siglo VI, respectivamente. Como juiciosamente ha afirmado R. MacMullen, a lo que se daba preferencia en estos casos era a la efectividad...16

Uno de los elementos que hacía más atractivas a las viejas religiones itálicas, célticas o germánicas era la afirmación de la existencia, junto al panteón de los grandes dioses, de una infinidad de divinidades "menores", de gran relieve para los fieles en tanto en cuanto se las consideraba presentes en cada uno de los pequeños momentos importantes de la vida del individuo: dioses domésticos, dioses rectores de la vida pastoril o agrícola, etc. Esta inflación de divinidades, ridiculizada por Agustín en su De ciuitate Dei,${ }^{17}$ ofrecía al individuo la seguridad de una presencia protectora de los dioses en cada momento de su vida, el sentimiento de una relación más íntima y constante con la esfera de lo sacro que la que propondría un estricto monoteísmo cris-

sanctus a partir de una base documental muy reducida: los "holy men" de Brown no dejan de ser personajes más o menos marginales, cuya incidencia en las relaciones sociales del Bajo Imperio fue muy limitada en el tiempo y en el espacio (cf. en este sentido la crítica implícita al artículo de Brown en PIETRI 1989, en especial 19; y uide asimismo, para una crítica explícita de la metodología histórica de Brown, TREADGoLD 1994, especialmente 155-157 sobre la "marginalidad" del "holy man" definido por Brown -como mucho, un $5 \%$ de la población tardoantigua habría tenido contacto con uno de estos individuos-).

15 Recuérdese en este sentido el rechazo de parte del episcopado galo a la imagen de asceta-taumaturgo de Martín de Tours (Sulpicius Seu., Vita Mart., 27, 3, Fontaine 1967, 314, o Id., Gallus siue Dial. 1, 26, 3-4, Fontaine 2006, 206-208: clérigos y obispos de la Galia no reconocen las uirtutes de Martín y alguno ha llegado a afirmar que la Vita Martini de Sulpicio contiene numerosas mentiras). La tensión entre la jerarquía eclesiástica institucional y estas figuras carismáticas que consiguieron una enorme autoridad entre las comunidades campesinas se constata aún en la Alta edad media europea. Ejemplo de ello es la figura de Aldeberto de Neustria, condenado como hereje por el sínodo de Soissons del 3 de marzo de 744, sentencia ratificada por un concilio romano en octubre de 745. De acuerdo con una carta enviada a la Sede Apostólica por Bonifacio -arzobispo de Neustria-Aldeberto, considerado por muchos cristianos un patronus, un uirtutum factor y un signorum ostensor, afirmaba haber recibido de un ángel las reliquias de un santo ignoto, las cuales le permitían obtener de Dios todo aquello que quisiera; de este modo obtuvo el reconocimiento, por parte de una multitudo rusticorum, como uir apostolicae sancTitatis, autor de numerosos signa et prodigia. Aldeberto llegó a consagrar oratorios dedicados a su propia persona y a repartir entre sus fieles sus pelos y uñas, a los que se reconocía un valor apotropaico similar al de las reliquias de los santos. Este homo sanctus sembró los campos de Neustria de pequeños oratorios donde las comunidades campesinas cristianas podían celebrar sus publicae orationes sin tener que hacer largos viajes hasta las iglesias episcopales. Finalmente, llegó a afirmar que poseía el don de conocer la intimidad de las conciencias de todos sus fieles, lo que hacía innecesaria la confesión pública de sus pecados -que perdonaba al instante- (uide la epístola de Bonifacio recogida en las actas del sínodo romano de 745, Conc. Rom. [745], ed. TANGL 1916, 108-120, en especial 110-112, y cf. igualmente MANSELLi 1982, en especial 89-94). El episodio de Aldeberto -quien fue más allá de lo que la joven Iglesia institucional de Neustria podía tolerar- nos recuerda en todo caso la importancia de estas figuras carismáticas en la cristianización de las zonas rurales de Europa aún en la Alta edad media.

16 MacMullen 2004, 211-212.

17 Cf., por ejemplo, Augustinus, De ciu. Dei 4, 8, ed. Dombart - Kalb 1955, 105, sobre las numerosas divinidades romanas vinculadas al crecimiento del trigo; o Id., De ciu. Dei 6, 9, Dombart - KaLb 1955, 178 179 , sobre los dioses relacionados con el matrimonio y el ciclo reproductor humano. 
tiano. ${ }^{18}$ Tales divinidades, finalmente integradas como demonios en la cosmología cristiana, hallarán su contrapartida en las figuras de los santos: mártires y ascetas del pasado y, en algunos casos - como hemos visto-, hombres cuya santidad y capacidad de intercesión ante el dios trascendente les fue reconocida aún en vida. En importante medida, el relato del triunfo del cristianismo sobre estos paganismos no es el del éxito del mensaje de la kénosis del Hijo de Dios, de su humillación por la salvación de todo el género humano, sino el de las sucesivas victorias de un dios todopoderoso, fuerte y vengador $-\mathrm{y}$ de su milicia, los santos mediadores entre él y el resto de los hombressobre las viejas divinidades paganas. ${ }^{19}$

Pero aunque quepa aceptar parcialmente la tesis según la cual la mentalidad de los estratos campesinos pre-modernos fue siempre muy poco receptiva al mensaje evangélico, huelga decir que esta tesis no explica suficientemente la lenta cristianización -en comparación con la de los núcleos urbanos- de las zonas rurales del Imperio. ${ }^{20}$ De hecho, no cabe acentuar demasiado, para el mundo antiguo, el antagonismo ciudad-campo: la mayoría de los habitantes de la mayoría de ciudades de esta época eran agricultores cuya mentalidad religiosa no diferiría demasiado de la de los pobladores de los uici. Y podríamos citar numerosos relatos localizados en un ambiente urbano de conversiones más o menos masivas al cristianismo cuyo desencadenante es la intervención de un santo-mediador que consigue interferir en el ciclo de la naturaleza. ${ }^{21}$

18 Manseldi, 1982, 83, a propósito de la Galia franca: "ne viene la conferma che il mondo contadino sentiva come più ristretto, più angusto, meno ricco $\mathrm{e}$, in fondo, meno rispondente alle proprie esigenze di vita spirituale, il cristianesimo, avvertendo la necessità di un divino più a sé prossimo, più pronto ad intervenire nei loro bisogni particolari, più especificamente aperto ai loro sentimenti particolari’.

19 Manselli 1982, 68, n. 17, a propósito del triunfo en la Alta edad media de una imagen del dios cristiano más cercana a la del Antiguo Testamento. Pero el formulario de las inscripciones cristianas preconstantinianas de Asia Menor -la región del Imperio que más testimonios epigráficos cristianos anteriores al siglo IV nos ha legado- expresa en la mayoría de los casos la confianza en un Dios juzgador, implacable y amenazante, siendo mucho menos frecuente el tema del Dios de amor y de paz que ha prometido a los creyentes la resurrección y la vida eterna (uide a este respecto Destephen 2010, en especial 168-170). Y no se olvide que el dios de Constantino es fundamentalmente un Yahvé de los Ejércitos.

20 Entendemos por cristianización la adhesión formal al cristianismo de una mayoría de la población y una más o menos completa implantación, en las prácticas religiosas de esta población, de un marco referencial estrictamente cristiano, en detrimento del viejo marco referencial pagano. Son cristianos, por ejemplo, los campesinos de Madaba que pedían al profeta Elías que les abriera los cielos y les trajera la lluvia (movidos a ello por la historia narrada en III Rg., 17, 1), como quizás hacían sus antepasados dirigiéndose en este caso a un dios local de la lluvia (cf. el mosaico, fechado en el s. VII, hallado en una iglesia de Madaba, citado por MacMullen 2004, 211). También son cristianos aquellos feligreses de Agustín que confesaban a su obispo que ellos eran cristianos para poder alcanzar así la vida eterna que la Iglesia les prometía (christiani autem sumus propter uitam aeternam) pero que no dejaban de ser inquisitores atque obseruatores temporum et dierum (Agustín se refiere aquí a aquella vertiente de la astrología denominada catárquica, que determinaba, a partir de la observación de los astros, si un determinado momento era propicio o no para realizar exitosamente algo), porque creían poder obtener de esta práctica respuestas válidas para su vida cotidiana (haec propter tempus hoc necessaria sunt), como el momento más adecuado para emprender una determinada acción (Augustinus, Enarr. in psalm. 40, 3, ed. DekKers -Fraipont 1956, 447-459, aquí 450-451). Creemos que -desde la perspectiva del historiador- no cabe ir mucho más allá en la definición de "cristianización".

21 Véase, por ejemplo, Marcus Diac., Vita Porph., 19-21, ed. GréGoIre - Kugener 1930, 16-18: numerosos habitantes paganos de la ciudad de Gaza se convierten al cristianismo después de contemplar cómo el obispo Porfirio, tras organizar una procesión, lleva la lluvia a la ciudad y pone fin a una larga sequía. Cristo ha derrotado a Zeus Marnas, a quien estos paganos creían señor de la lluvia. Ninguna diferencia, por tanto, con las narraciones de conversiones en las zonas rurales de las que acabamos de hablar. 
La lenta expansión del cristianismo en los territorios rurales del Imperio se ha tratado también de explicar aduciendo que los pastores cristianos compartían con las elites urbanas - de las que frecuentemente formaban parte- cierto menosprecio hacia los rustici, los estratos campesinos. De acuerdo con R. MacMullen, por ejemplo, la predicación cristiana antigua habría sido un discurso elaborado por miembros de las elites ilustradas -los obispos- dirigido exclusivamente a los integrantes de estas mismas elites urbanas. Siempre según MacMullen, los obispos de esta época no se preocuparon demasiado por hacerse entender por aquellos rustici que pudieran encontrarse entre su audiencia: un campesino iletrado de lengua céltica, púnica o siríaca que se hallara eventualmente en la ciudad apenas podía entender nada de un sermón pronunciado en griego o latín y construido con todos los artificios de la retórica clásica. ${ }^{22} \mathrm{Y}$ es cierto que Martín de Tours, evangelizador en los campos galos, fue en buena medida un outsider en el episcopado galorromano de su época: muchos de sus colegas, ya lo hemos visto, rechazaban esa imagen de santo carismático, obrador de milagros entre los campesinos, que los martinianos estaban divulgando de su maestro; ${ }^{23}$ no pocos obispos juzgaban además que este antiguo militar era indigno de formar parte de su colegio - entre otras razones- por carecer de erudición, elocuencia y pureza de lenguaje, es decir, por ser ajeno a la paideía clásica. ${ }^{24}$ Pero, como acertadamente ha señalado E. G. Clark -en respuesta a la tesis de MacMullen-, no debemos olvidar que las homilías de esta época que han llegado hasta nosotros son sólo una pequeña muestra de la predicación cristiana contemporánea: en efecto, no son sino aquellas que, a lo largo de la historia, se creyó necesario preservar por su calidad literaria o didáctica. Por ello conocemos los sermones de Basilio de Cesarea, pero no los de los cincuenta chorepiscopi del territorio capadocio; y sabemos además que Agustín no permitió a su diácono Lucilo dejar la diócesis de Hipona para reencontrarse con su hermano -también obispo-, muy probablemente porque Lucilo era imprescindible para la pastoral de la diócesis hiponense a causa de su conocimiento de la lengua púnica hablada por los campesinos de la zona, que prácticamente desconocían el latín. ${ }^{25}$ Teodoreto de Ciro, por su parte, nos informa de que el monje Mesima, hijo él mismo de una familia campesina, fue consagrado presbítero en una aldea de las

22 Cf. MacMullen 1989. El autor ha insistido en esta tesis en MacMullen 2004, 24-25 o 104, donde afirma a propósito de los obispos: "bien entendu, la campagne figurait aussi peu ou aussi rarement dans leur esprit que dans celui de leurs homologues laïques, dont les préoccupations étaient toujours centrées sur la ville".

23 Vide supra, n. 15.

24 Como cabe inferir de Sulpicius Seu., Vita Mart., 25, 6-8, FontaIne 1967, 310-312, donde Sulpicio, dirigiéndose a un público cristiano letrado, hace por el contrario una apología de la sabiduría y de la elocuencia de su maestro -sabiduría y elocuencia, empero, estrictamente carismáticas y evangélicas, las de las gentes indoctas a las que Jesús escogió para ser sus apóstoles- (cf. FonTAINE 1969, 1066-1077). Cf. igualmente Sulpicius Seu., Gallus siue Dial. 1, 26, 6, Fontaine 2006, 208, pasaje en el que Sulpicio, en respuesta a quienes dudaban de las virtudes carismáticas de Martín, acusa a éstos de ampararse en estas críticas para no reconocer su propia inertia: el pasaje ha sido interpretado por J. Fontaine como una denuncia de la falta de iniciativa evangelizadora del campo por parte de esos obispos instalados en las ciudades que, impregnados de la altiva cultura de las elites urbanas, criticaban los relatos extraordinarios que se habían construido en torno a las misiones de Martín en las zonas rurales (cf. la nota ad loc. en la citada edición de Fontaine).

25 Augustinus, Epist. 84, 2, ed. Goldbacher 1898, 392-393, en especial 393, con Clark 2001. 
cercanías de Antioquía a causa de su conocimiento del siríaco. ${ }^{26}$ No podemos negar, por tanto, que al menos algunos obispos trabajaron para difundir el mensaje cristiano entre los campesinos ajenos a la cultura urbana grecolatina. De cualquier modo, es incuestionable que la autoridad episcopal se debilitaba a medida que sus depositarios se alejaban de los núcleos urbanos. Y este hecho, como vamos a ver a continuación, iba a condicionar enormemente la imposición en las zonas rurales del Imperio de la política de homogeneización religiosa de la dinastía teodosiana. Tras la declaración del cristianismo niceno como religión oficial del estado romano y la prohibición de los cultos paganos o cristianos heterodoxos, el campo se iba a revelar como el más sólido bastión de la disidencia religiosa.

\section{LEGISLACIÓN IMPERIAL ANTIPAGANA Y PATRONAZGO URBANO Y RURAL}

Es bien sabido que, desde el reinado de Constantino, los obispos fueron adquiriendo una cada vez mayor autoridad en muchas ciudades del Imperio. Gracias a la acción caritativa desplegada por la Iglesia en beneficio de los estratos sociales más desfavorecidos -acción social que abarcaba a aquellos grupos excluidos del evergetismo cívico tradicional, como los peregrini o los mendigos en general-, ${ }^{27}$ los obispos"patrones de los pobres" se convirtieron en un auténtico contrapoder urbano, una de aquellas figuras de gran autoridad local cuya colaboración debían asegurarse el gobierno imperial y sus representantes en las provincias para preservar el orden y la paz social en las ciudades. ${ }^{28}$ Los obispos, por su parte, podían servirse de su creciente influencia entre las masas urbanas para forzar al emperador a colaborar con ellos en una política tendente a barrer a los cultos paganos del espacio público urbano: ejemplar en este sentido es la actuación de Teófilo en el episodio de la destrucción del Serapeion de Alejandría. ${ }^{29}$ Frecuentemente, sin embargo, el obispo no era tan poderoso más allá de la ciudad. En las regiones rurales el poder fáctico estaba en manos de otros patronos, los grandes propietarios de tierras.

Los domini ejercían un poder casi absoluto sobre los habitantes de sus explotaciones agrarias, fueran aquéllos siervos o colonos. Un poder que se proyectaba también a la esfera religiosa: la legislación de la dinastía teodosiana atestigua que el gobierno imperial era plenamente consciente de que sólo con la colaboración de los grandes

26 Theodoretus Cyr., Hist. relig., 14, 2, CANIVET 1977-1979, t. II, 10.

27 Cf. el -tantas veces citado- testimonio de Juliano el Apóstata, Iulianus Imp., Epist. 84, ed. BIDEz 1972, 144-147. Esta "acción social" llevada a cabo por la Iglesia -y que Juliano quiso transplantar a su nueva "Iglesia pagana"- había sido posibilitada, en buena medida, por los beneficios económicos concedidos por diversos emperadores desde Constantino. Vide, por ejemplo, Eusebius Caes., Vita Const. 3, 58, ed. Winkelmann 1975, 111; o Athanasius Alex., Apol. contra Arian., 18, 2, ed. Opitz 1938-1940, 100 (el pasaje en cuestión corresponde a la epístola del sínodo alejandrino de 338).

28 BRown 1998, 127-163.

29 Vide el relato de Sozomenus, Hist. ecc. 7, 15, 2-10, ed. BIDEZ 19952, 319-321, que revela la astucia política de Teófilo. Cf. asimismo Rufinus Aquil., Hist. ecc. 2 (11), 22-23, ed. Mommsen 1908, 957-1040, en especial 1025-1030; y Socrates Schol., Hist. ecc. 5, 16, ed. Hansen 1995, 289-290. Remito también a los análisis de Leppin 2008, 197-204, o ChUvin 2009³, 70-74. 
propietarios de tierras podía imponerse en el campo la política de unificación religiosa perseguida por Teodosio y sus sucesores. El dominus podía forzar la conversión de sus dependientes a su propia confesión o bien, simplemente, no preocuparse en absoluto de sus prácticas religiosas -dentro de poco veremos ejemplos de ambas actitudes-. Lo cierto es que tanto los obispos de la Gran Iglesia como las autoridades civiles del Imperio, oficialmente cristiano niceno desde la Cunctos populos de Teodosio (CTh. 16, 1, 2, del 28 de febrero de 380), debían tener presente la autonomía de facto de la que gozaban los grandes domini en sus fundi si querían extirpar el paganismo de las zonas rurales del Imperio e imponer en ellas el cristianismo niceno. El lenguaje coactivo de las leyes y el persuasivo de la predicación fueron los instrumentos de los que se sirvieron para tratar de implicar a los domini en esta política.

Diversas leyes del Códice Teodosiano, en efecto, atestiguan que los emperadores de la dinastía teodosiana no renunciaron a imponer su política religiosa en los dominios de los grandes señores terratenientes. Una ley de Teodosio, dirigida en 392 al prefecto del pretorio de Oriente Rufino, prohíbe diversas prácticas religiosas paganas, públicas y privadas -como la veneración de los Lares y Penates-, algunas de las cuales eran características del paganismo rural-suspender cintas de árboles sagrados, por ejemplo-.$^{30}$ La ley prevé la confiscación de aquellas domus o possessiones en las que su propietario hubiera realizado prácticas de este tipo. ${ }^{31}$ En el supuesto de que tales actos de culto hubieran sido llevados a cabo en templos públicos o bien en edificios o tierras que no eran propiedad del transgresor de la ley sin que el propietario tuviera conocimiento de ello (ignorante domino), la constitución prescribe la imposición de una multa de 25 libras de oro sólo al infractor; pero en el caso de que el dominus sí tuviera constancia de la realización de tales prácticas en sus propiedades y las tolerara, su coniuentia debería ser castigada con la misma multa impuesta al ejecutor efectivo de tales actos de culto. ${ }^{32}$ La ley, por tanto, trataba de implicar a los domini, con la amenaza de sanciones, en la erradicación de las prácticas paganas de sus dependientes. En 407, una constitución de Honorio dirigida al prefecto del pretorio de Italia -a la sazón Curcio- establecía una serie de medidas a tomar en relación con los templos dedicados al culto pagano: aquellos edificios que se hallaran in ciuitatibus uel oppidis uel extra oppida debían ser destinados a funciones públicas tras ser privados de las estatuas de los dioses (simulacra) que todavía pudiera haber

30 Cod. Theod. 16, 10, 12 (8 de noviembre de 392), Mommsen [en] Mommsen - Meyer 1905, 900-901, aquí 900: nullus omnino ex quolibet genere ordine hominum dignitatum uel in potestate positus uel honore perfunctus, siue potens sorte nascendi seu humilis genere condicione fortuna in nullo penitus loco, in nulla urbe sensu carentibus simulacris uel insontem uictimam caedat uel secretiore piaculo larem igne, mero genium, penates odore ueneratus accendat lumina, inponat tura, serta suspendat.

31 Ibid.: si quis uero mortali opere facta et aeuum passura simulacra inposito ture uenerabitur ac ridiculo exemplo, metuens subito quae ipse simulauerit, uel redimita uittis arbore uel erecta effossis ara cespitibus, uanas imagines, humiliore licet muneris praemio, tamen plena religionis iniuria honorare temptauerit, is utpote uiolatae religionis reus ea domo seu possessione multabitur, in qua eum gentilicia constiterit superstitione famulatum. Namque omnia loca, quae turis constiterit uapore fumasse, si tamen ea in iure fuisse turificantium probabuntur, fisco nostro adsocianda censemus.

32 Ibid.: sin uero in templis fanisue publicis aut in aedibus agrisue alienis tale quispiam sacrificandi genus exercere temptauerit, si ignorante domino usurpata constiterit, uiginti quinque libras auri multae nomine cogetur inferre, coniuentem uero huic sceleri par ac sacrificantem poena retinebit. 
en ellos; ${ }^{33}$ los altares donde se ofrecían sacrificios a los dioses paganos debían ser destruidos allí donde se encontraran, ${ }^{34}$ mientras que los templos emplazados en los dominios imperiales debían ser igualmente "desafectados" y destinados a usos adecuados y conformes a la ley; ${ }^{35}$ en cuanto a los templos situados en propiedades privadas, la ley especificaba que los domini propietarios de estas tierras debían, sin más, ser obligados a destruirlos: domini destruere cogantur. ${ }^{36} \mathrm{El}$ distinto trato reservado a los templos urbanos, periurbanos o emplazados en los dominios imperiales y a los situados en dominios privados responde sin duda -entre otras razones- a la certitud de que estos últimos, cuya ubicación les alejaba del control de los agentes imperiales -o de las autoridades eclesiásticas- seguirían siendo el centro del culto de los campesinos paganos si no se procuraba arrasarlos hasta sus cimientos -lo que la ley prevé, no sin cierta ingenuidad voluntarista-.

En efecto, es bien sabido que -pese a su agresiva retórica- estas leyes fueron ampliamente transgredidas. Citaremos aquí tan sólo un ejemplo que, si bien no concierne a la legislación antipagana, sí atestigua suficientemente el abismo que existía entre la retórica de las leyes religiosas de los emperadores de la casa teodosiana y sus reales posibilidades de aplicación. De acuerdo con el testimonio del Contra litteras Petiliani de Agustín de Hipona, Crispino, el obispo donatista de Calama, obtuvo el arriendo enfitéutico de una possessio de la res priuata en África Proconsular; como cabía esperar, Crispino obligó a todos los colonos de esta propiedad -bautizados en la Iglesia católica- a someterse a un nuevo bautismo, de acuerdo con la práctica donatista. ${ }^{37}$ Ello atestigua que -como ya hemos apuntado- el propietario o el conductor de una possessio ejercía un poder casi absoluto sobre sus dependientes: podía llegar a imponerles su fe-si se preocupaba de estas cosas-. Lo que nos interesa ahora subrayar es que una ley de Teodosio, del año 392, había impuesto una multa de diez libras de

33 Cod. Theod. 16, 10, 19, Mommsen [en] Mommsen - Meyer 1905, 902-903, aquí 903 (=Const. Sirmond. 12, del 15 de noviembre de 408, Mommsen [en] Mommsen - Meyer 1905, 916-917): simulacra, si qua etiamnunc in templis fanisque consistunt et quae alicubi ritum uel acceperunt uel accipiunt paganorum, suis sedibus euellantur, cum hoc repetita sciamus saepius sanctione decretum. Aedificia ipsa templorum, quae in ciuitatibus uel oppidis uel extra oppida sunt, ad usum publicum uindicentur. Una ley de 399, dirigida al procónsul de África Apolodoro, ya había establecido que los edificios de los templos debían ser respetados una vez se hubiera eliminado de ellos "todo lo que es ilícito" (aedes inlicitis rebus uacuae); las estatuas de los dioses que todavía fueran objeto de culto, en efecto, debían ser puestas bajo la supervisión del officium del procónsul (Cod. Theod. 16, 10, 18, del 20 de agosto de 399, Mommsen [en] Mommsen - Meyer 1905, 902, y cf. asimismo Cod. Theod. 16, 10, 15 [29 de agosto de 399], Mommsen [en] Mommsen - MeYer 1905, 901902). Respecto a la voluntad imperial de preservar los edificios de los viejos templos urbanos y las estatuas de los dioses en reconocimiento de su valor artístico, asegurando empero su total desafección de culto pagano, cf. asimismo Cod. Theod. 16, 10, 8 (30 de noviembre de 382), Mommsen [en] Mommsen - Meyer $1905,899$.

34 Cod. Theod. 16, 10, 19, Mommsen [en] Mommsen - Meyer 1905, 903: arae locis omnibus destruantur.

35 Ibid.: omniaque templa in possessionibus nostris ad usus adcommodos transferantur.

$36 \mathrm{Ibid}$. Una constitución de 399 ya había ordenado la destrucción, sin alborotos, de los templos emplazados in agris -sin mayor concreción-. Cf. Cod. Theod. 16, 10, 16 (10 de julio de 399), Mommsen [en] MommSENMeyer 1905, 902.

37 Augustinus, Contra litt. Pet. 2, 83, 184, ed. Petschenig 1909, 3-227, aquí 114: nonne Crispinus uester Calamensis cum emisset possessionem et hoc emphyteuticam, non dubitauit in fundo catholicorum imperatorum, quorum legibus nec in ciuitatibus esse iussi estis, uno terroris impetu octoginta ferme animas miserabili gemitu mussitantes rebaptizando submergere? 
oro tanto a los clérigos de grupos heréticos, ${ }^{38}$ como a los conductores de propiedades imperiales que toleraran la celebración de reuniones de grupos cristianos heterodoxos en los fundi del emperador. ${ }^{39}$ Pese a ello, un agente de la res priuata no tuvo problema alguno en arrendar tierras del emperador a un obispo donatista, quien podía incurrir en dos de los delitos que contemplaba la citada constitución. ${ }^{40}$ Como brillantemente ha resumido R. MacMullen, el ímpetu absolutista de las leyes religiosas de los emperadores de la casa teodosiana se rebajaba en el nivel local debido tanto a la venalidad de los funcionarios teóricamente encargados de aplicarlas como a la necesidad de acomodarse a los imperativos de la realidad o de buscar un cierto compromiso con las autoridades locales. ${ }^{41}$ De cualquier modo, el episodio del obispo donatista de Calama nos muestra bien una de las vías de expansión del cristianismo en las zonas rurales del Imperio. Las iglesias cristianas, constituidas en agentes económicos en estos territorios a través de la adquisición o el arriendo de grandes propiedades, podían imponer su credo a sus dependientes, como hizo Crispino. Los presbíteros que gestionaban un dominio propiedad de su iglesia - o bien del que ésta había obtenido el arriendo- debían ser a su vez los guardianes de la ortodoxia y de la legalidad de la fe de aquellos campesinos vinculados a estas tierras. ${ }^{42}$

Dado que la fuerza de una constitución se disolvía sobremanera una vez ésta salía del officium del quaestor sacrii palatii, al lenguaje coactivo de las leyes debió añadirse la capacidad de persuasión de los obispos para tratar de obtener la colaboración de

38 Cod. Theod. 16, 5, 21 (15 de junio de 392), Mommsen [en] Mommsen - Meyer 1905, 862-863, aquí 862: in haereticis erroribus quoscumque constiterit uel ordinasse clericos uel suscepisse officium clericorum, denis libris auri uiritim multandos esse censemus.

39 Ibid.: tum illud specialiter praecauemus, ut, si uilla dominica fuerit seu cuiuslibet publici iuris et conductor et procurator licentiam dederint colligendi, denis libris auri proposita condemnatione multentur.

40 La ley que aquí nos ocupa fue promulgada en la diócesis de África, pues Agustín indica en una carta a Crispino que está en su mano promover la imposición al obispo donatista de la multa de las diez libras de oro (cf. Augustinus, Epist. 66, 1, ed. GoldBACHER 1898, 235-236, aquí 235: nam possemus agere, ut decem libras auri secundum imperatoria iussa persolueres) -y de hecho, el procónsul de África se la acabó imponiendo tras la agresión sufrida por el obispo católico Posidio de manos de un presbítero de Crispino, cf. MANDOUZE 1982, 252-253, Crispinus 1-. Mayor dificultad plantea, en todo caso, la cuestión de hasta qué punto Crispino incurría realmente en los delitos contemplados en la ley -como afirmaba Agustín-, en tanto en cuanto en ella se menciona exclusivamente a los herejes, y el cisma donatista no fue legalmente asimilado a una herejía hasta el llamado "decreto de unión" de Honorio (Cod. Theod. 16, 6, 4, del 12 de febrero de 405, MommSEN [en] MommSEn - MeYer 1905, 881-882).

41 MacMullen 2004, 40-45. Si hay que dar crédito a la Vida de Porfirio de Gaza de Marco el Diácono, el propio emperador podía reconocer - en la intimidad- la necesidad de anteponer la Realpolitik a la defensa de la fe cristiana. En efecto, de acuerdo con este documento, hacia el año 409 Arcadio habría admitido ante Porfirio, obispo de la pequeña comunidad cristiana de Gaza, que no podía imponer el cierre del templo de Zeus Marnas en esa ciudad, en la que la mayoría de los habitantes -y entre ellos los principales de la curia municipal- eran paganos. Dado que la ciudad pagaba puntualmente sus impuestos, era preferible no sembrar en su población la desafección hacia el emperador con una medida como el cierre del Marneion (cf. Marcus Diac., Vita Porph., 41, GrÉgoire - Kugener 1930, 35). Allí donde la ejecución de las leyes religiosas podía enfrentarse a una fuerte oposición por parte de la población, y sobre todo de las autoridades locales -como los principales de Gaza- de las que dependía la paz social - el obispo de Gaza no había conseguido convertirse en una de esas autoridades-, incluso el más cristiano de los emperadores estaba obligado a transigir.

42 Cf., para el caso de África, Buenacasa 2004, 503-504; LeOne 2006, 101. 
los domini en la erradicación del paganismo rural. ${ }^{43}$ Una serie de homilías pronunciadas por Máximo de Turín en ocasión de la conmemoración del dies natalis de los tres mártires de Val di Non (Trento), brillantemente analizadas por R. Lizzi, nos revelan las estrategias de persuasión de las que podían servirse los obispos para alcanzar este objetivo. ${ }^{44}$

Conocemos la historia del martirio de los clérigos Alejandro, Martirio y Sisino de Val di Non -acontecido en el año 397- gracias fundamentalmente al relato que de tal hecho hizo el obispo Vigilio de Trento a Simpliciano de Milán y Juan Crisóstomo (Vigilius, Epp. 1-2). Estos tres clérigos servían en una iglesia rural del citado valle, donde desde hacía sólo poco tiempo se había empezado a difundir el mensaje cristiano. En cierta ocasión en que atravesaban el valle, los tres clérigos toparon con una lustratio, una procesión propiciatoria de la fertilidad de la tierra celebrada en el marco de los Ambarualia; cuando Alejandro y sus dos colegas vieron que en la procesión participaban algunos neófitos cristianos, trataron de apartarlos de ella para evitar su apostasía, lo que generó un tumulto en el que perdieron la vida los tres clérigos.

Máximo de Turín, refiriéndose a estos hechos con ocasión del aniversario del martirio, modifica algunos detalles de la historia narrada por Vigilio. De acuerdo con las homilías pronunciadas por Máximo en honor de los tres clérigos martirizados, no habría sido sólo por evitar la apostasía de algunos cristianos -arrancándolos de la procesión, pero dejando que ésta siguiera su curso- que aquéllos habrían encontrado el martirio: según Máximo, el tumulto y el consecuente linchamiento se habrían producido porque Alejandro y sus colegas habrían tratado de poner fin a la celebración de la lustratio. En estas homilías, el obispo de Turín se dirige a los domini cristianos que se hallan entre su audiencia, a quienes reprocha la indiferencia con la que aceptan que se sigan celebrando cultos paganos en sus propiedades. Máximo les presenta el ejemplo de los mártires de Val di Non: siguiendo su modelo, los domini cristianos deben esforzarse por extirpar las prácticas paganas de sus tierras. ${ }^{45} \mathrm{El} \mathrm{de}$ Turín insinúa que estos mártires quisieron acabar con la procesión pagana porque eran plenamente conscientes de que ésta no contaminaba sólo a los participantes, sino también a quienes, aun no desfilando en ella, habían tolerado que tuviera lugar -los domini propietarios de las tierras donde se celebraba la lustratio- ${ }^{46}$ Como ha apun-

43 Agustín señala en su sermón 62 que los cristianos deben procurar extirpar la idolatría de los corazones de los domini paganos: una vez conseguido esto, ellos mismos se encargarán de destruir cualquier vestigio de culto pagano en sus fundi, o bien invitarán a sus nuevos correligionarios a hacerlo. En este sermón - pronunciado en Cartago probablemente en 399-, el obispo de Hipona afirma que los cristianos carecen de la potestas para destruir los elementos de culto idolátrico presentes en las propiedades privadas rurales. Cf. Augustinus, Sermo 62, 11, 17, ed. Coppieters't Wallant - De Coninck - Demeulenaere 2008, 296-313, aquí 311 .

44 Retomo en las líneas siguientes el excelente análisis de Lizzi 2010, en especial 95-102.

45 Maximus Taur., Sermo 105 extr., 2, ed. Mutzenbecher 1962, 414-415, aquí 415: haec ergo tota causa passionis est, fratres, propter quam morti addicti sancti uiri, cur sui similes esse ceteros hortarentur; Id., Sermo 106 extr., 1-2, Mutzenbecher 1962, 417-418.

46 Id., Sermo 106 extr., 1, MutZENBECHER 1962, 417: nam cum perspicerent in regione sua gentiles homines adsueto sacrilegio quod lustrum uocant funestis circuitionibus loca uniuersa polluere, et innocentes quosque uel absentes si non conscientia uel coniuentia maculare-maculat enim coniuentia eum qui, cum contradicendo prohibere potuit ne fieret, ut fieret quasi dissimulando permisit-. 
tado R. Lizzi, la insistencia de Máximo en el pecado / delito de coniuentia del que se harían culpables los domini cristianos demasiado tibios a la hora de enfrentarse a sus campesinos paganos no pretendía sino recordar a sus oyentes las leyes imperiales que preveían sanciones contra los propietarios que toleraban la práctica de los viejos cultos en sus dominios. ${ }^{47}$

En la iglesia donde Máximo pronunció estas homilías había no pocos domini cristianos que no se preocupaban demasiado de lo que sus dependientes hacían en sus posesiones. Máximo les informa de que la idolatría de sus campesinos no les deja sin mácula, que el sacrilegio de un solo individuo puede contaminar a muchos ${ }^{48}$ y que si continúan viviendo de los productos de dominios mancillados por los ritos paganos, ellos se verán igualmente mancillados. ${ }^{49}$ Máximo recomienda a estos domini que, cuando salgan de la iglesia y vuelvan a sus tierras, permanezcan atentos: unas brasas aún humeantes en una cella pueden probar que allí se ha celebrado un sacrificio, un campesino ebrio puede haber ofrecido una libación a Diana... ${ }^{50} \mathrm{Y}$ tales actos de idolatría, cometidos en sus propiedades, no dejan de contaminarles. Todo esto concierne también a su propia salvación. ${ }^{51}$

\section{EL ASCETISMO ARISTOCRÁTICO CRISTIANO IN RURE Y LA EXPANSIÓN DEL CRISTIANISMO}

En Turín, Máximo se dirige a unos grandes terratenientes cristianos la tibieza de cuya fe es objeto de sus críticas y de quienes quiere obtener la colaboración en la extirpación de las prácticas paganas de los campesinos adscritos a sus fundi. Quizás estos domini urbanos no visitaban sus propiedades rurales sino en contadas ocasiones. Pero debemos tener presente que hacia finales del siglo IV y principios del V asistimos también al fenómeno de la expansión del ascetismo cristiano entre las clases aristocráticas del Imperio. Es en esta época, en efecto, que un buen número de aristócratas se retiran a sus dominios rurales con el objetivo de llevar, lejos de las ciudades, una vida regida por el Evangelio. ${ }^{52}$ Los secessus in uillam de nobles cristianos atraídos

47 Cf., además del pasaje citado en la nota anterior, Id., Sermo 107 extr., 1, Mutzenbecher 1962, 420-421, especialmente 420. Cabe subrayar que, de acuerdo con Máximo, correspondía en efecto a los domini ser en sus dominios los exsecutores de las leyes imperiales: principes quidem tam boni christiani leges pro religione promulgant, sed eas exsecutores non exerunt conpetenter (Id., Sermo 106 extr., 2, MutZENBECHER 1962, 418).

48 Id., Sermo 106 extr., 2, MutzenBECHER 1962, 417-418: nam sicut unius sanctitate sanctificantur multi, ita unius sacrilegio plurimi polluuntur.

49 Id., Sermo 107 extr., 2, Mutzenbecher 1962, 420: non potest non esse pollutus, ubi cibum capit quem sacrilegus cultor exercuit terra cruenta edidit taetrum horreum conseruauit.

50 Id., Sermo 107 extr., 2, ibid.

51 Respecto a la presión ejercida por la jerarquía eclesiástica sobre los grandes propietarios para comprometerlos en la extirpación del paganismo rural uide asimismo DuMÉzIL 2005, 414-427.

52 Respecto a la confluencia, en la espiritualidad cristiana de ascetas aristocráticos de época gracianoteodosiana -como Paulino de Nola y Prudencio (o incluso Ausonio)- de unos valores estrictamente escriturísticos y de "disciplina evangélica" y otros profundamente enraizados en la "sabiduría antigua" (meditación poética y filosófica sobre la rusticatio y la elevación, a partir de la sabiduría práctica del cultivo de la tierra, hacia la contemplación de la divinidad), valores antiguos bien vivos gracias al estudio, lectura e imitación de los prosistas y poetas clásicos, uide el extraordinario estudio de FonTAINE 1972. 
por el ascetismo en esta época contribuyeron sin duda a la expansión del cristianismo entre los estratos campesinos del Imperio. Uno de estos aristócratas, Prudencio, esboza en su Contra Symmachum la imagen del "dominus cristiano ideal”, aquel que se esfuerza por erradicar de sus dominios los cultos paganos: utimur et ruris reditu, et ratione colendi / exercere manum non paenitet: et lapis illic / si stetit, antiquus quem cingere sueuerat error / fasceolis, uel gallinae pulmone rogare, / frangitur, et nullis uiolatur Terminus extis, / et quae fumificas arbor uittata lucernas / seruabat, cadit ultrici succisa bipenni. ${ }^{53}$ Así, para el periodo comprendido entre principios del siglo V y mediados del VII, L. Pietri ha censado la existencia en territorio galo de alrededor de treinta oratoria in agro propio, capillas o iglesias edificadas en dominios privados por iniciativa de sus propietarios -aristócratas galorromanos en una primera fase y más tarde, siguiendo su ejemplo, dignatarios burgundios y francos, eclesiásticos y monjes hijos de familias acaudaladas-. Algunos de estos oratorios servirían únicamente a la devoción privada de sus fundadores, pero en muchos otros casos se trataba de auténticas iglesias rurales que reunían a la población de los dominios en los que estaban emplazadas, con presbíteros a su servicio. ${ }^{54}$ En dos casos -uno de ellos la célebre fundación de Sulpicio Severo en Primuliacum- está atestiguada la existencia de un baptisterio anejo al oratorio, ${ }^{55}$ lo que atestiguaría el interés de sus fundadores por la evangelización de la población campesina del territorio.

La jerarquía eclesiástica, sin embargo, contempló no sin ciertas reticencias el auge de esta suerte de iniciativa privada en la cristianización del territorio rural. El autonomismo religioso de estos aristócratas laicos convertidos, algunas de cuyas prácticas parecían revelar una voluntad de independencia respecto a la Iglesia institucional,

53 Prudentius, Contra Symm. 2, vv. 1005-1011, ed. Lavarenne 1948, 134-196, aquí 192. Es digno de notar que el rápido y estereotipado retrato del paganismo rural que Prudencio ofrece en este pasaje parece hacerse eco de algunas prácticas también alusivamente citadas en la constitución contra el paganismo del 8 de noviembre de 392 (Cod. Theod. 16, 10, 12, citada supra, nn. 30-32). Cf. la prohibición de encender lámparas (accendere lumina) o suspender cintas de los árboles sagrados (redimita uittis arbor) en la citada ley, con el v. 1010 de este pasaje de Prudencio (et quae fumificas arbor uittata lucernas); o la prohibición de ofrecer a las estatuas de dioses paganos aún ofrendas de mínimo valor (uanas imagines, humiliore licet muneris praemio ... honorare), con la alusión de Prudencio a la estatua (lapis) que es ornada de cintas o a la que se ofrece el pulmón de una gallina (vv. 1006-1008). Si Prudencio conoció el texto de esta constitución, es probable que estos versos del Contra Symmachum se propusieran esbozar el retrato de un dominus cristiano estricto exsecutor en sus dominios de las leyes antipaganas de los emperadores, a diferencia, por ejemplo, de los grandes señores del territorio de Turín a los que se dirigía Máximo en sus homilías.

54 Una ley de 398, dirigida al prefecto del pretorio de Oriente, da asimismo prueba de la abundancia en esta zona del Imperio de iglesias fundadas en dominios privados (Cod. Theod. 16, 2, 33, del 27 de julio de 398 , Mommsen [en] Mommsen - Meyer 1905, 846: ecclesiis, quae in possessionibus, ut adsolet, diuersorum ... sunt constitutae). En defensa de los intereses del fisco, la ley prohíbe la ordenación como clérigos al servicio de estas iglesias de individuos censados en otras posesiones (cf. igualmente Cod. Iust. 1, 3, 16, del 28 de febrero de 409, ed. Krueger $1929^{10}$, 20, y el comentario de Delmaire 2005, 187, n. 3 ).

55 En Primuliacum, Sulpicio construyó en un primer momento -hacia 397- un santuario con funciones de oratorio privado, junto al que edificó posteriormente un baptisterio - hacia 401- y una basílica de mayores dimensiones -hacia 402-, destinada a una comunidad más numerosa formada por esclavos y colonos del dominio. Vide PIETRI 2005, en especial 236-237. Alrededor de 15 baptisterios en zonas rurales están arqueológicamente documentados en la Galia meridional para el periodo comprendido entre el siglo IV y el VIII. Cf. Codou et alii 2007, especialmente 61-66 -quienes apuntan que la fundación de iglesias bautismales en territorio rural respondería a la iniciativa episcopal, con la notable excepción de Primuliacum-. 
fue percibido como una amenaza contra la unidad de la plebs Dei y, por supuesto también, contra la autoridad del obispo. En la Italia Suburbicaria, los obispos romanos Pelagio I (556-561) y Gregorio I (590-604) establecieron una reglamentación tendente a acabar con esta creciente autarquía religiosa aristocrática: si ya Gelasio I (492-496) había prohibido la fundación de iglesias en dominios rurales privados sin autorización expresa del obispo de Roma, Pelagio I estableció que las nuevas fundaciones podrían servir únicamente a la devoción privada, vetando la celebración en ellas de misas públicas, la vinculación permanente a su servicio de un presbítero y la construcción de un baptisterio anejo al oratorio, reglamentación restrictiva que fue aplicada sistemáticamente por Gregorio Magno. ${ }^{56}$ También en Galia, diversos concilios del siglo VI trataron de frenar un proceso que amenazaba con erosionar la autoridad del obispo en su diócesis, haciendo de los grandes dominios rurales una suerte de pequeñas diócesis con una vida religiosa autónoma bajo la supervisión de los propietarios. Así, por ejemplo, los padres conciliares de Agde (506) establecieron que todos los fieles de una diócesis debían celebrar la Pascua, la Navidad, la Epifanía, la Ascensión, Pentecostés y el dies natalis de San Juan Bautista en la iglesia episcopal o bien en una iglesia rural dependiente de ésta -se prevé la pena de excomunión para el clérigo que en estos días celebre misa en un oratorio privado sin autorización de su obispo-.${ }^{57}$ Más tarde, los obispos asistentes al concilio de Clermont (535) precisarían -revelando de este modo cuál era su real inquietud- que la obligación de celebrar estas festividades en la ciudad, en presencia del obispo, no afectaba a todos los fieles de las zonas rurales, sino únicamente a los laicos ilustres (ciues natu maiores). ${ }^{58}$

Ya en el último cuarto del siglo IV hay testimonios de la creciente tensión entre la jerarquía eclesiástica y un sector de la aristocracia cristiana cuyas prácticas religiosas -que adoptan como escenario privilegiado los dominios rurales- parecen querer escapar a su control. Tal tensión fue, por ejemplo, el desencadenante de la crisis priscilianista. En efecto, existe hoy cierto consenso historiográfico a la hora de explicar esta controversia como el resultado del conflicto entre dos modelos opuestos de dirección de las comunidades cristianas, a saber, el "carismático" y el "institucional". 59 Prisciliano, pastor carismático, halló numerosos adeptos sobre todo entre los nobiles

56 Vide PIETRI 2002, en especial 254-261.

57 Conc. Agath. (506), c. 21, ed. Munier 1963, 193-228, aquí 202-203: si quis etiam extra parrocias, in quibus legitimus est ordinariusque conuentus, oratorium in agro habere uoluerit, reliquis festiuitatibus ut ibi missas teneant propter fatigationem familiae iusta ordinatione permittimus; Pascha uero, Natale Domini, Epiphaniam, Ascensionem Domini, Pentecosten et Natale sancti Ioannis Baptistae, uel si qui maximi dies in festiuitatibus habentur, nonnisi in ciuitatibus aut in parrociis teneant. Clerici uero, si qui in his festiuitatibus quos supra diximus, in oratoriis nisi iubente aut permittente episcopo missas facere aut tenere uoluerint, a communione pellantur.

58 Conc. Clar. seu Aru. (535), c. 15, ed. De Clerce 1963, 105-112, aquí 109: si quis presbyter adque diaconus, qui neque in ciuitate neque in parrochiis canonecus esse dinuscitur, sed in uillolis habitans, in oraturiis officio sancto deseruiens celebrat diuina mysteria, festiuitatis praecipuas: Domini natale, pascha, pentecosten et si quae principalis festiuitatis sunt reliquae, nullatenus alibi nisi cum episcopo suo in ciuitate teneat. Quicumque etiam sunt ciues natu maiores, pari modo in urbibus ad pontifices suos in praedictis festiuitatibus ueniant. Quod si qui inproba temeritate contimpserint, hisdem festiuitatibus, in quibus in ciuitate adesse despiciunt, communione pellantur. Cf., sobre toda esta cuestión, PIETRI 2005, 237-238.

59 Cf. en este sentido la excelente síntesis de Escribano 2002, en especial 214-215. 
cristianos de Lusitania y de Aquitania atraídos por el ascetismo. Y algunos de los cánones concernientes a las prácticas priscilianistas promulgados por el concilio de $\mathrm{Za}$ ragoza (hacia 378-379) atestiguan que la inquietud suscitada en parte de la jerarquía eclesiástica por el movimiento priscilianista fue de naturaleza similar a la generada entre los obispos romanos o galos del siglo VI por el fenómeno de los oratoria in agro propio: inquietud ante la emergencia de una vida cristiana in rure -impulsada por los grandes domini- que pueda desarrollar formas organizativas no controladas por los obispos, el centro de cuyo poder se hallaba en las ciudades. Así, el canon 2 de Zaragoza prohíbe a los fieles -junto al ayuno dominical- ausentarse de las iglesias durante la Cuaresma y sustituir en este período las asambleas comunitarias presididas por miembros de la jerarquía institucional por conuentus en uillae particulares. ${ }^{60} \mathrm{En}$ este mismo sentido, el canon 4 del citado concilio condena a quien se ausente de las iglesias durante las tres semanas previas a la Epifanía, reemplazando las asambleas comunitarias por el retiro en domus y las reuniones en uillae o en el campo ${ }^{61}$ En este absentismo de la iglesia episcopal y en la celebración de reuniones en uillae rurales privadas, los obispos reunidos en Zaragoza creyeron ver una amenaza contra su autoridad en el seno de la comunidad cristiana. La acusación de heterodoxia religiosa vertida contra Prisciliano y sus adeptos por algunos obispos trataría así de poner freno a unas prácticas religiosas que parecían cuestionar su monopolio de la mediación entre Dios y los cristianos.

Es indudable que cuanto menos algunos de aquellos laicos conuersi que se retiraron a sus dominios rurales para llevar en ellos una vida más evangélica lo hicieron impulsados por un espíritu de rechazo a la jerarquía católica institucional. Tal fue el caso, por ejemplo, de uno de los primeros y más ilustres de los aristócratas galorromanos convertidos al ascetismo, Sulpicio Severo. Es bien sabido que Sulpicio estaba enfrentado con la mayor parte de los obispos galos de su tiempo. En sus tres grandes obras, el discípulo de Martín de Tours no ahorra críticas a la avidez de riquezas, ambición de poder, vanidad, arrogancia o servil sumisión al poder político del episcopado

60 Conc. Caesar. (378-379), c. 2, ed. RodríguEz 1981, 15-25, aquí 19-20: ne quis ieiunet die Dominica causa temporis aut persuasionis aut supprestitionis; aut de quadragesimarum die ab ecclesiis non desint nec habitent latibula cubiculorum ac montium qui in his suspicionibus perseuerant, sed exemplum et praeceptum custodiant sacerdotum, et ad alienas uillas agendorum conuentuum causa non conueniant.

61 Conc. Caesar. (378-379), c. 4, RodríGuez 1981, 21-22: uiginti et uno die quo a sextodecimo Kalendas Ianuarias usque in diem epiphaniae, qui est octauo Idus Ianuarias, continuis diebus nulli liceat de ecclesia absentare nec latere in domibus, nec sedere ad uillas nec montes petere nec nudis pedibus incedere, sed concurrere ad ecclesiam. Quod qui non obsernauerit de susceptis, anathema sit in perpetuum. Vide en este sentido el estudio de Bowes 2001, en especial 335-348, quien relaciona el inicio de la controversia priscilianista con un supuesto auge de la edilicia cristiana de iniciativa privada en los dominios rurales y con las dificultades de la jerarquía episcopal para controlar este fenómeno de expansión del cristianismo en el campo bajo liderazgo de los domini. Pero cf. asimismo ChAVARRía 2006, en especial 212-224, quien rechaza que los primeros testimonios arqueológicos de iglesias en uillae privadas hispanas puedan fecharse en los siglos IV-V, cuando éstas aún funcionaban como residencias aristocráticas. Es cierto, sin embargo, que -como la misma autora señala- el canon 5 del primer concilio de Toledo parece atestiguar la existencia en uillae hispanas de edificios de culto cristianos, integrados en la estructura diocesana (cf. Conc. Tol. [400], c. 5, ed. MartíneZ - Rodríguez 1984, 323-344, aquí 330). 
galorromano. ${ }^{62}$ Como tantos autores cristianos habían hecho -antes aún de la "svolta constantiniana"-, Sulpicio evoca la Iglesia de los mártires para criticar la de su época, ajada por los enfrentamientos que provoca la ambición del episcopado. ${ }^{63} \mathrm{El}$ secessus de Sulpicio en su villa de Primuliacum parece inspirado por la certitud de que en la ciudad, escenario de todas esas luchas de poder entre facciones eclesiásticas que el noble aquitano reprueba, no se puede vivir plenamente el cristianismo. ${ }^{64}$ Es significativo en este sentido que Paulino de Nola, cuya espiritualidad ascética aristocrática era compartida por Sulpicio, elogie en su epístola 32 a su corresponsal Aper -otro laico convertido al ascetismo "rústico"- porque éste frecuentaba poco la ciudad y se mantenía lejos de los forensibus turbis aemuli tumultus ecclesiarum y de los concilia inquieta (posible alusión a la división provocada en el episcopado galo por el proceso de Prisciliano y a los concilios convocados para ponerle fin). ${ }^{65}$

Si bien es cierto que Sulpicio no cuestiona en ningún momento el fundamento de las acusaciones vertidas contra Prisciliano, no lo es menos que en sus obras el aquitano dirige las más duras diatribas precisamente contra los obispos acusadores de Prisciliano y de sus discípulos -reales o supuestos-. Objeto privilegiado de la crítica de Sulpicio contra estos obispos es la facilidad con la que acusaban de herejía a cualquiera que se entregara a la lectura y a la abstinencia. ${ }^{66} \mathrm{La}$ espiritualidad de muchos cristianos que se dedicaban a un estudio personal de la literatura sagrada y cuyas prácticas ascéticas dejaban en evidencia la mediocridad moral postulada por el episcopado galo fue -siempre de acuerdo con la denuncia sulpiciana-injustamente tachada de herejía en los convulsos años inmediatamente anteriores y posteriores a los juicios de Tréveris. Tras reseñar el proyecto del emperador Magno Máximo de enviar tribunos a Hispania para perseguir a los adeptos de Prisciliano y confiscar sus propiedades, Sulpicio comenta que era incuestionable que esta "caza de brujas" orquestada por la autoridad civil y eclesiástica (la "expedición" había sido sugerida a Máximo por los obispos que estaban en comunión con Itacio de Ossonoba) iba a

62 Cf. Sulpicius Seu., Chron. 1, 23, ed. Halm 1866, 3-105, aquí 26 (críticas a la habendi cupido de los obispos); Id., Chron. 2, 51, Halm 1866, 105 (arrogancia, avaricia, rivalidades personales que dividen al episcopado galo y una acusación de desidia deprauata que puede entenderse como una crítica a la falta de pulsión evangelizadora de los obispos galos, de igual modo que la inertia atacada en Id., Gallus siue Dial. 1, 26, 6, Fontaine 2006, 208, cf. supra, n. 24); Id., Gallus siue Dial. 1, 2, 3-4, Fontaine 2006, 108-110; Id., Gallus siue Dial. 1, 21, 1-4, Fontaine 2006, 184-186; Id., Gallus siue Dial. 2, 1, 3, Fontaine 2006, 216; o Id., Vita Mart., 20, 3-7, Fontaine 1967, 296-298, el episodio de Martín de Tours en la mesa del emperador Magno Máximo, que sirve a Sulpicio para atacar la sumisión general del episcopado galo a las autoridades políticas. Sulpicio evita en sus obras la idealización de los emperadores cristianos y pretende inspirar en su audiencia una actitud crítica ante los excesos del poder temporal, tentado siempre por el absolutismo, hecho puesto de relieve, por ejemplo, en el proceso contra Prisciliano. Cf. a este respecto FonTAINE 1976.

63 Sulpicius Seu., Chron. 2, 32, Halm 1866, 86. La percepción crítica de una "mundanización" de las comunidades cristianas es, en efecto, un tema ya recurrente en diversos autores cristianos anteriores a Constantino. Cf., a este respecto, PERrin 2010, en especial 54-58.

64 Sobre las ciudades como hogar de todos los vicios: Sulpicius Seu., Chron. 1, 48, Halm 1866, 50: frequens tum incolentium multitudine, alens uirorum milia $C$ et XX atque ut in magno populo abundans uitiis.

65 Cf. Paulinus Nol., Epist. 38, 10, ed. Hartel 1999, 323-334, aquí 332-333, con Fontaine 1972, $581-582$.

66 Cf. Sulpicius Seu., Chron. 2, 50, Halm 1866, 103: Sulpicio recrimina a Itacio de Ossonoba haber acusado de Priscilliani socii aut discipuli a todos los sancti uiri, quibus aut studium inerat lectionis aut propositum erat certare ieiuniis. 
afectar a muchos buenos fieles cristianos, pues entonces se acusaba injustamente de herejía a quien era rico, a quien la palidez de su rostro delataba por sus frecuentes ayunos o a quien vestía con modestos ropajes. ${ }^{67}$ En otro revelador pasaje de sus Diálogos, Sulpicio nos habla de una virgen cristiana que vivía retirada en un dominio rural, lejos de las miradas de los hombres. En el transcurso de un viaje que le llevó cerca del dominio do residía la virgen, Martín de Tours quiso saludarla personalmente y departir con ella, a lo que la virgen, cortésmente, se negó. De acuerdo con el relato de su biógrafo, Martín, lejos de enojarse por el aparente desplante de la virgen, alabó su propósito de santidad. Y esta actitud del obispo de Tours es contrapuesta a la que habría tenido cualquiera de sus colegas en el episcopado en la misma situación: éstos no habrían dudado, según Sulpicio, en acusar de herética a la monja y en anatematizarla (quis autem hoc praeter Martinum sacerdos non ad suam iniuriam rettulisset? Quos aduersum sanctam uirginem motus quantasque iras mente concepisset? Haereticam iudicasset et anathemandam esse decreuisset). ${ }^{68}$ Más allá de su evidente tono apologético, nos parece que este pasaje atestigua el conflicto existente en la Galia de finales del siglo IV entre una parte de la jerarquía eclesiástica y un incipiente movimiento aristocrático de ascetismo in rure que parecía tratar de hurtarse al control de la Iglesia institucional, conflicto éste que los obispos podían tratar de resolver recurriendo al expediente de la acusación de herejía. Si los domini cristianos de fe tibia podían suponer un obstáculo para la expansión del cristianismo en las zonas rurales, al tolerar el paganismo de los habitantes de unas tierras sobre las que ejercían un dominio que no aceptaba injerencias, el retiro a sus propiedades rurales, lejos de la ciudad y de los obispos, de muchos domini cristianos atraídos por la rusticitas ascética-domini que, de acuerdo por ejemplo con la imagen que de ellos nos quiere dar Prudencio, podían asumir la "misión" entre sus colonos- generó una creciente tensión con la jerarquía católica, tensión que eventualmente adoptó la morfología de un conflicto entre ortodoxia y heterodoxia ${ }^{69}$ Frente a la ciudad, consolidada cada vez con mayor fuerza como bastión del poder episcopal y de la ortodoxia, el campo parece adquirir la imagen de feudo de la disidencia religiosa -real o imaginada- en el Imperio cristiano.

\section{DISIDENCIA CRISTIANA Y GRANDES DOMINIOS RURALES}

Más allá de lo fundamentado o no de las acusaciones de heterodoxia doctrinal vertidas contra los ascetas de origen aristocrático en la Galia o en la Hispania de finales del siglo IV y principios del V, no deja de ser cierto que el campo, y sobre todo los grandes dominios señoriales, sirvieron en no pocas ocasiones de refugio a los grupos cristianos disidentes del Imperio teodosiano. Como ya hemos apuntado, el poder de

67 Id., Gallus siue Dial. 3, 11, 4-5, FonTAINE 2006, 330-332.

68 Id., Gallus siue Dial. 2, 12, 1-9, FonTAINe 2006, 268-272.

69 Poco puede sorprender que tampoco Sulpicio Severo fuera inmune a las acusaciones de heterodoxia doctrinal (pelagianismo), siempre y cuando haya que conceder crédito a la noticia de Gennadius, De uir. inl., 19, ed. RichARDSON 1896, 57-97, aquí 69: hic in senecta sua a Pelagianis deceptus et agnoscens loquacitatis culpam silentium usque ad mortem tenuit, ut peccatum quod loquendo contraxerat, tacendo penitus emendaret. 
los obispos, su capacidad de incitar a las masas populares y a las autoridades civiles a actuar de acuerdo con sus intereses, se debilitaba considerablemente fuera del ámbito urbano. Así, tras haber sido condenado por el concilio de Zaragoza -aunque no nominalmente- y haber sido expulsado del episcopado de Ávila por un rescripto del emperador Graciano, Prisciliano se dirigió a Italia junto a algunos de sus discípulos para reclamar la abolición del citado rescripto y acusar a su vez a Hidacio de Mérida -promotor del sínodo zaragozano-- ${ }^{70}$ a su paso por Aquitania, Prisciliano fue expulsado de la ciudad de Burdeos por el obispo Delfín -quien había asistido al concilio zaragozano-, pero el prelado no pudo evitar que el proscrito encontrara refugio en los dominios de la rica Eucrocia en el territorio bordelés, donde su proselitismo hizo numerosos adeptos -entre ellos, la propia domina- ${ }^{71}$ Tiempo más tarde, Úrbica, discípula de Prisciliano, ${ }^{72}$ muere lapidada por la turba en la ciudad de Burdeos. ${ }^{73}$ Cabría preguntarse si quienes participaron en la lapidación no lo hicieron bajo el fervor provocado por la predicación antipriscilianista del obispo bordelés: la terrible ejecución de Úrbica, en efecto, debe sin duda relacionarse con las acusaciones de magia negra vertidas contra Prisciliano y sus seguidores. De cualquier modo, estos dos episodios tan cercanos en el espacio y en el tiempo atestiguan que los dominios rurales escapaban frecuentemente a la capacidad de acción de los obispos, cuyo poder, sin embargo, crecía en las ciudades gracias a su capacidad de movilizar a las masas. La persecución dirigida por el obispo romano León I (440-461) contra el cripto-maniqueísmo romano -entre 443-444- nos ofrece un nuevo ejemplo de ello. ${ }^{74}$

Muy probablemente tras haber recibido informes previos denunciando la presencia en Roma de miembros de la Iglesia maniquea, León desata en la ciudad un auténtico proceso inquisitorial, convocando a sus fieles a arrancar a los maniqueos de la clandestinidad y a denunciarlos ante los presbíteros de sus tituli. La predicación proporciona al obispo romano la posibilidad de establecer lo que acertadamente se ha calificado de "panóptico ortodoxo": ${ }^{75}$ cada cristiano debe convertirse en celoso escrutador de las prácticas religiosas de su vecino, al que debe denunciar ante la más mínima sospecha de heterodoxia. Muchos maniqueos, en efecto, acudían a las iglesias católicas para disimular su confesión religiosa y evitar que la sospecha recayera sobre ellos. León proporciona a sus feligreses, empero, la información necesaria para detectarlos: en el momento de la comunión, los electi tomarán la hostia pero rechazarán beber el vino, respetando de este modo los tabúes alimentarios que obligaban al electus maniqueo. ${ }^{76}$

La llamada general a la delación lanzada por León alcanzó el objetivo deseado: diversos maniqueos fueron denunciados y conducidos ante un tribunal constituido por el prelado romano, otros obispos y clérigos, y representantes del senado de Roma.

70 VILeLla 1997, aquí 516-522.

71 Sulpicius Seu., Chron. 2, 48, Halm 1866, 101.

72 Probablemente hija de un rhetor bordelés, cf. Piay Augusto 2006, en especial 607.

73 Prosper Aquit., Epit. Chron., a. a. 385, ed. Mommsen 1892, 385-485, aquí 462: Burdigalae quaedam Priscilliani discipula nomine Urbica ob impietatis pertinaciam per seditionem uulgi lapidibus extincta est.

74 Para lo que sigue, me permito remitir a VilLEgas Marín 2004, estudio que resumo aquí sucintamente.

75 Tomo el concepto de MAIER 1996.

76 Cf. Leo I, Tract. 42, 5, ed. Chavasse 1973, 238-250, aquí 247-248. 
Los acusados confesaron su pertenencia a la Iglesia de Manes. Algunos se mostraron dispuestos a abjurar de su error, mientras que quienes no lo hicieron fueron condenados a exilio perpetuo por los tribunales públicos. En los albores de la persecución, sin embargo, algunos maniqueos habían huido de Roma: León escribió a los obispos italianos para pedirles que velaran a fin de que los fugitivos no hallaran refugio entre sus fieles. ${ }^{77}$ Sabemos que algunos de estos fugitivos alcanzaron la lejana Astorga, donde residía una pequeña comunidad maniquea de la que los romanos conocían la existencia. Esta comunidad, sin embargo, había sido delatada por sus correligionarios de la Vrbs ante León: éste informó al obispo católico de Astorga quien, a su vez, expulsó de la ciudad a todos los miembros de la Iglesia de la Luz. ${ }^{78}$ Tiempo más tarde Pascencio, maniqueo huido de Roma y de Astorga, fue arrestado por el obispo Antonino de Mérida, quien ordenó su expulsión de la provincia lusitana. ${ }^{79}$ Es posible, sin embargo, que el hereje y disidente Pascencio hallara refugio en una comunidad rural del territorio emeritense, donde pudo acabar sus días: en efecto, se ha sugerido su identificación con el personaje homónimo mencionado en un epitafio hallado en la necrópolis de Torrebaja (Pueblonuevo del Guadiana, en las cercanías de Mérida). ${ }^{80}$

Diversos aspectos de este episodio histórico reclaman la atención de nuestro estudio: en primer lugar, la omnipotencia y la libertad de acción de la autoridad episcopal en la Roma de mediados del siglo V, su capacidad de movilizar a sus fieles contra una comunidad heterodoxa reducida, en la ciudad, a la clandestinidad; a continuación, la existencia en esta época de una red episcopal bien consolidada, en el seno de la cual la información circula a gran velocidad, lo que provoca que, tras la caída de la estructura maniquea romana, otras comunidades urbanas de esta iglesia, aún en el extremo occidental del Imperio, sufran su misma suerte; $y$, finalmente, las comunidades rurales como lugar de refugio, o de exilio interior, para los herejes expulsados de las ciudades -como probablemente fue el caso de Pascencio-. No deja de ser significativo que la constitución promulgada por Valentiniano III en apoyo de la campaña inquisitorial leonina incluya una cláusula que prohíbe explícitamente a los maniqueos residir en las ciudades. ${ }^{81}$

De hecho, diversas leyes promulgadas por los emperadores de la casa teodosiana contra los cristianismos disidentes parecen tomar en consideración exclusivamente los límites de la ciuitas a la hora de prohibir las actividades de estos grupos heréticos. Así, una ley de Teodosio - del 10 de enero de 381-prohíbe a las comunidades

77 Id., Epist. 7, 2, ed. BALLERINI 1846, cc. 620-622, cc. 621-622.

78 Ydatius, Cont. Chron., a. a. 445, ed. Burgess 1993, 70-123, aquí 96.

79 Id., Cont. Chron., a. a. 448, Burgess 1993, 98.

80 Vide SAn Bernardino 1997. El texto de la inscripción y un completo análisis, con reseña bibliográfica, pueden hallarse en la web del equipo español -coordinado por J. Gómez Pallarès-que trabaja en la redacción del fascículo 2 del volumen XVIII del CIL, dedicado a los carmina latina epigraphica (http://www. clehispania.com/pdf/conpac/Ba18.pdf); veáse, también, $\operatorname{HEp~14,~2005,~61,~con~toda~la~bibliografía~precedente.~}$ La paleografía permite fechar la inscripción a mediados del siglo $\mathrm{V}$ y hay que subrayar también que Pascentius es un nombre muy poco documentado en Hispania -sólo vuelve a aparecer en una pizarra visigótica del siglo VI-.

81 Nou. Valent. III, 18 (19 de junio de 445), Meyer [en] Mommsen - Meyer 1995, 103-105, aquí 104: ut nouerint uniuersi hac edictali lege proposita Manichaeos dignitate militiae et urbium habitatione priuandos, ne quis innocens talium conuersatione aut societate capiatur. 
cristianas no nicenas la celebración de asambleas en las ciudades (cum omnes haereticos inlicitas agere intra oppida congregationes uetemus) y ordena explícitamente la expulsión de los ámbitos urbanos (ab ipsis etiam urbium moenibus) de quienes se atrevieran a ignorar la interdicción..$^{82}$ Una constitución de mayo de ese mismo año, destinada como la anterior al prefecto del pretorio del Ilírico -Eutropio- extiende la prohibición de celebrar reuniones litúrgicas en ámbitos urbanos -y en especial, en Constantinopla- a los maniqueos. ${ }^{83}$ En este mismo sentido, tres años más tarde Teodosio ordena al prefecto del pretorio de Oriente, Cinegio, la expulsión de Constantinopla de los clérigos eunomianos, macedonianos, arrianos y apolinaristas: in aliis locis uiuant ac penitus a bonorum congressibus separentur, así concluye el extracto de esta ley preservado en el Teodosiano. ${ }^{84}$ Otra constitución dirigida al prefecto del pretorio de Oriente prohíbe la reunión de asambleas heréticas en Constantinopla y su periferia (intra urbem seu in suburbanis). ${ }^{85}$ En diversas constituciones antiheréticas de los sucesores de Teodosio se menciona exclusivamente a la ciudad como ámbito de prohibición de las actividades de los grupos cristianos heterodoxos. ${ }^{86}$

Estas leyes no atestiguan sino la pervivencia en la mentalidad del emperador y de la intelligentsia de la administración central de las viejas concepciones que identificaban civilización con vida urbana: más allá de la red de ciuitates / póleis que articula el Imperio se abre un mundo indefinido sobre el que el emperador parece en ocasiones renunciar a ejercer su potestad y que es aparentemente cedido a la heterodoxia religiosa, a la que se procura sobre todo aislar de la humana communio urbana. ${ }^{87}$ Pero ello no debe llevarnos a la conclusión de que la autoridad imperial aceptaba hacer del campo una suerte de no man's land cuya situación marginal respecto a la civilización

82 Cod. Theod. 16, 5, 6 (10 de enero de 381), Mommsen [en] Mommsen - Meyer 1905, 856-857, aquí 857.

83 Cod. Theod. 16, 5, 7 (8 de mayo de 381), Mommsen [en] Mommsen - Meyer 1905, 857-858, aquí 858: ne in conuenticulis oppidorum, ne in urbibus claris consueta feralium mysteriorum sepulcra constituant; a conspectu celebri ciuitate penitus coherceantur.

84 Cod. Theod. 16, 5, 13 (21 de enero de 384), Mommsen [en] Mommsen - Meyer 1905, 860.

85 Cod. Theod. 16, 5, 19 (26 de noviembre de 389), Mommsen [en] Mommsen - Meyer 1905, 862. En este mismo sentido, Cod. Theod. 16, 5, 29 (24 de noviembre de 395), Mommsen [en] Mommsen - Meyer $1905,864-865$, prescribe de nuevo la expulsión de los herejes únicamente de Constantinopla, aunque ello se explique en este caso porque la constitución pretende purgar de herejes la administración del palacio imperial (su destinatario es el magister officiorum Marcelo).

86 Cf. Cod. Theod. 16, 5, 31-32 (de 21-22 de abril de 396, a Cesario prefecto del pretorio de Oriente), Mommsen [en] Mommsen - Meyer 1905, 865: los auctores doctoresque enomianos deben ser expulsados $e$ ciuitatibus; Cod. Theod. 16, 5, 33 (1 de abril de 397), Mommsen [en] Mommsen - Meyer 1905, 866: expulsión de Constantinopla de los doctores Apollinariorum; Cod. Theod. 16, 5, 30 (3 de marzo de 402), Mommsen [en] Mommsen - Meyer 1905, 865: expulsión de Constantinopla de los clérigos de los grupos heréticos (el extracto preservado en el Teodosiano pertenece a la constitución dirigida al prefecto de la ciudad); Const. Sirmond. 6 (a Amacio, prefecto del pretorio de las Galias, 9 de julio de 425), Mommsen [en] Mommsen - Meyer 1905, 911-912, aquí 912: Manichaeos omnesque haereticos uel schismaticos siue mathematicos omnemque sectam catholicis inimicam ab ipso aspectu urbium diuersarum exterminari debere praecipimus (y cf. por ejemplo Cod. Theod. 16, 5, 62 -ejemplar de esta misma ley enviado al prefecto de Roma Fausto el 17 de julio-, Mommsen [en] Mommsen - Meyer 1905, 877, expulsión de estos grupos usque ad centesimum lapidem de Roma -tal era el límite de la jurisdicción del praefectus Vrbi-).

87 Particularmente representativo en este sentido es el texto de Cod. Theod. 16, 5, 14 (10 de marzo de 388), Mommsen [en] Mommsen - Meyer 1905, 860: Apollinarianos ceterosque diuersarum haeresum sectatores ab omnibus locis iubemus inhiberi, a moenibus urbium, a congressu honestorum, a communione sanctorum ... adeant loca, quae eos potissimum quasi uallo quodam ab humana communione secludant. 
urbana ofreciera vía libre a la alteridad religiosa. Los emperadores de la casa teodosiana trataron también de proyectar su política de unificación religiosa y de combate contra la disidencia cristiana en las zonas rurales. Toparon, sin embargo, con el obstáculo del que hemos hablado a propósito de la legislación antipagana: la autonomía de los domini en sus señoríos rurales. La insistencia con la que las leyes prohíben la celebración de asambleas y reuniones de culto de grupos heréticos en los fundi da prueba tanto de que estos territorios sirvieron en no pocas ocasiones de refugio para la disidencia cristiana, como de los problemas que la autoridad imperial tenía para proyectar su autoridad sobre ellos.

Meses después de la ley que había prohibido a los grupos cristianos no nicenos la celebración de asambleas litúrgicas en las ciudades, Teodosio prohíbe a estos mismos grupos la construcción de iglesias in agris, ordenando la confiscación de domus y fundi que hubieran acogido sus reuniones ${ }^{88}$ Con los sucesores de Teodosio, las leyes relativas a los herejes in rure se tornan más precisas. Una constitución de Arcadio, de 398 , ordena la expulsión de las ciudades de los clérigos eunomianos y montanistas y la deportación de aquellos que habiten en zonas rurales y hayan llevado a cabo asambleas con finalidades proselitistas: se prevé la pena de muerte para el procurator de una possessio que haya acogido tales asambleas, así como la confiscación de la citada propiedad en el supuesto de que el dominus no ignorara la celebración en ella de reuniones montanistas y eunomianas. ${ }^{89}$ En años sucesivos se reiterarán medidas similares -con variaciones respecto a las penas-contra diferentes grupos heréticos presentes en las zonas rurales del Imperio, con el objetivo de implicar no sólo a los domini, sino a también a sus procuratores -quienes lógicamente tenían un contacto más directo con la vida de los fundi- en la erradicación de la heterodoxia cristiana. ${ }^{90}$

88 Cod. Theod. 16, 5, 8 (al comes Orientis Glicerio, del 19 de julio de 381), Mommsen [en] MommSEN Meyer 1905, 858, donde sólo se menciona a eunomianos, arrianos y seguidores del anomeo Aecio; Cod. Theod. 16, 5, 12 (a Postumiano, prefecto del pretorio de Oriente, del 3 de diciembre de 383), MommSEN [en] MommSEN - MeYer 1905, 859-860, hace extensivas a macedonianos y apolinaristas las medidas de la ley anterior. Entre ambas leyes, Cod. Theod. 16, 5, 9 (31 de marzo de 382), Mommsen [en] Mommsen - Meyer 1905, 858-859, prohíbe la celebración de asambleas de encratitas, hydroparastatas y sacóforos agris ... moenibus. Nótese que ya Graciano había prohibido en Occidente la reunión de coetus haeretici tanto en las ciudades como en el campo, ordenando la confiscación de las propiedades que hubieran acogido tales reuniones (Cod. Theod. 16, 5, 4, del 22 de abril de 378, Mommsen [en] Mommsen - Meyer 1905, 867-868).

89 Cod. Theod. 16, 5, 34 (a Eutiquiano, prefecto del pretorio de Oriente, 4 marzo de 398, Mommsen [en] Mommsen - Meyer 1905, 866). Estas medidas son reiteradas en Cod. Theod. 16, 5, 36 (6 de julio de 399), Mommsen [en] Mommsen - Meyer 1905, 866-867, donde se menciona exclusivamente a los eunomianos.

90 Cod. Theod. 16, 5, 40 (22 de febrero de 407), Mommsen [en] Mommsen - Meyer 1905, 867-868: confiscación de praedia donde tuvieran lugar asambleas de maniqueos, frigios y montanistas en caso de que el dominus no ignorara su celebración -si la ignorara, el castigo debería volverse contra actores y procuratores, condenados a las minas tras latigazos, o bien contra los conductores libres, para los que la ley prevé pena de deportación-; Cod. Theod. 16, 6, 7 (29 de marzo de 413), Mommsen [en] Mommsen - Meyer 1905, 883884, confiscación de domus y agri donde hubieran tenido lugar asambleas eunomianas con conocimiento del dominus; Cod. Theod. 16, 5, 57 (31 de octubre de 415), Mommsen [en] Mommsen - Meyer 1905, 875, confiscación de domus y possessiones que acogieran reuniones montanistas con conocimiento del dominus, en caso contrario se prescribe el exilio para los procuratores; Cod. Theod. 16, 5, 58 (6 de noviembre de 415), Mommsen [en] Mommsen - Meyer 1905, 875-876, prohibición de acoger conuenticula eunomianos en possessiones, bajo pena de confiscación; Cod. Theod. 16, 5, 65 (30 de mayo de 428), Mommsen [en] Mommsen - Meyer 1905, 878-879: prohibición a arrianos, macedonianos y apolinaristas de poseer iglesias intra nullam 
Esta legislación coactiva tuvo cierta incidencia, pues de una ley de 395, dirigida al prefecto del pretorio de Oriente, Rufino, parece desprenderse que los coetus inliciti haeretici se celebraban cada vez con mayor frecuencia no tanto en propiedades privadas -legalmente amenazadas de confiscación- sino en los mismos dominios del emperador (la constitución amenaza a los procuratores que permitieran tales asambleas con las multas correspondientes). ${ }^{91}$

En las provincias africanas convulsionadas por el donatismo, sin embargo, las leyes imperiales que trataron de poner fin al cisma se enfrentaron a una dura oposición. Una constitución de 377 atestigua que los donatistas, expulsados de las ciudades, se refugiaban en los grandes dominios rurales, cuya confiscación prevé la ley. ${ }^{92}$ Es sabido, en efecto, que muchos propietarios africanos apoyaban a los donatistas: en 405 se prohíbe a los domini rebautizar a sus esclavos y colonos, bajo amenaza de confiscación de sus bienes. ${ }^{93}$ Como se ve, en no pocos casos se imponía el principio cuius dominus eius religio. Así, una constitución del 30 de enero de 412 establece una serie de multas a pagar por los fieles donatistas, dependiendo el montante de la sanción del rango de los culpables -se menciona a uiri inlustres, spectabiles, senadores y clarissimi-. La citada normativa encomienda a los domini la misión de obligar a entrar en la unidad católica a sus serui y coloni donatistas -para los colonos se sugiere el recurso a los latigazos-: la falta de colaboración de los grandes señores en la misión unificadora es amenazada con las correspondientes multas. ${ }^{94}$

Pero más allá de la agresividad de su lenguaje, ya hemos comentado las limitadas posibilidades de efectiva aplicación en el territorio africano de toda esta legislación. La política de unificación religiosa promovida desde el gobierno central no podía

ciuitatem, interdicción a novacianos y sabbatianos de construir nuevos edificios de culto; de manera más general se establece que los eunomianos, valentinianos, montanistas, frigios, marcionitas, donatistas y otros grupos gnósticos no pueden celebrar reuniones de culto in Romano solo, y los maniqueos deben ser expulsados de las ciudades; las propiedades donde estos grupos realizaran reuniones domino permittente deben ser transferidas a la Iglesia católica, el procurator que tolerara tales reuniones sin saberlo el dominus deberá pagar una multa de diez libras de oro o ser condenado a exilio si es de condición libre, o bien ser castigado a las minas tras los vergajazos de rigor si es de condición servil; Cod. Theod. 16, 5, 66 (3 de agosto de 435), Mommsen [en] MommSen - Meyer 1905, 879-880, nadie puede ceder a los seguidores de Nestorio en Constantinopla una casa, una uilla campestre o una propiedad suburbana, so pena de confiscación.

91 Cod. Theod. 16, 10, 13 (7 de agosto de 395), Mommsen [en] Mommsen - Meyer 1905, 901.

92 Cod. Theod. 16, 6, 2 (17 de octubre de 377), Mommsen [en] Mommsen - Meyer 1905, 880-881, aquí 881: sed plerique expulsi de ecclesiis occulto tamen furore grassantur, loca magnorum domorum seu fundorum inlicite frequentantes, quos fiscalis publicatio conprehendet, si piaculari doctrinae secreta praebuerint.

93 Cod. Theod. 16, 6, 4 (12 de febrero de 405), Mommsen [en] Mommsen - Meyer 1905, 881-882. La ley prevé además la confiscación de loca uel praedia donde se hubieran celebrado reuniones donatistas toleradas por los domini. Si eran los conductores o los procuratores los que autorizaban tales asambleas sin saberlo el propietario, aquéllos deberían ser castigados con latigazos y exiliados a perpetuidad. Además, la constitución establece que los esclavos obligados a rebautizarse podían buscar refugio en las iglesias católicas y ser manumitidos.

94 Cod. Theod. 16, 5, 52 (30 de enero de 412), Mommsen [en] Mommsen - Meyer 1905, 872-873. En esta constitución se establece además que los conductores y procuratores -incluidos los de la domus imperial-que no presentaran ante el exsecutor de la ley a aquellos circumcelliones que estuvieran bajo sus órdenes deberían ser sancionados, así como la confiscación, en beneficio de la Iglesia católica, de iglesias, lugares de reunión y propiedades donatistas. Y cf. igualmente Cod. Theod. 16, 5, 54 (17 de junio de 414), Mommsen [en] Mommsen - Meyer 1905, 873-874. 
imponerse sin la colaboración de los grandes propietarios rurales, colaboración que las leyes trataron de obtener por la vía de la amenaza y la coacción. Por otro lado, obispos católicos como Agustín trataron de aportar su capacidad de persuasión para granjearse la anhelada cooperación de los nobles en la lucha contra el donatismo. Así, Celer, un aristócrata de Hipona pasado del donatismo al catolicismo, recibe poco después de su conversión una epístola de Agustín en la que éste le invita a luchar contra la pervivencia del cisma en el seno de sus dominios. Más aún, Agustín menciona en su carta el nombre de los dos empleados de Celer, Paterno y Mauricio, que, a su juicio, serían los hombres mejor dotados para devolver a la unidad católica a los campesinos de los dominios del gran señor hiponense. ${ }^{95}$ Agustín no sugiere ningún procedimiento para la extirpación del donatismo entre los dependientes de Celer: el empleo de la violencia en estos casos allait de soi, como atestigua la ley del Teodosiano a la que acabamos de referirnos. Y, sin embargo, es de sobra conocido que pese a todos los esfuerzos conjuntos de emperadores y obispos católicos -a veces con la capacidad de persuasión de Agustín- el donatismo tenía una mala salud de hierro cuando los vándalos hicieron su aparición en la escena norteafricana.

\section{CONCLUSIONES}

Es quizás innecesario volver a decirlo aquí: el triunfo del cristianismo en el Imperio romano no fue -o no sólo fue- un proceso llamémosle "natural", resultado del surgimiento en amplios estratos de la población de nuevas exigencias espirituales a las que las religiones paganas, a diferencia del kérygma cristiano, no pudieron dar respuesta. Los paganismos eran una realidad viva, que subvenía a las necesidades religiosas de buena parte de la población del Imperio, cuando Teodosio I construyó un auténtico programa de acción política en torno al concepto de ortodoxia. ${ }^{96}$ Ya hemos señalado que los relatos del triunfo del cristianismo forjados en esta época son generalmente relatos de la victoria humillante de un dios fuerte y poderoso sobre los viejos dioses paganos, de los que se revelaba entonces su naturaleza maléfica y diabólica, que había sumido en el engaño a la humanidad durante siglos. A menudo, por tanto, una historia de violencia entre dioses, y también entre hombres.

Porque, retomando y reformulando una célebre sentencia de P. Brown, ${ }^{97}$ el triunfo del cristianismo fue el triunfo de los hombres al servicio del dios cristiano: los holy men liminales y más o menos marginales de Brown, pero también los emperadores, las jerarquías institucionales de las iglesias o los grandes aristócratas cristianos que detentaban el poder económico y social efectivo en el territorio. El análisis de la cristianización del Imperio debe por tanto tener bien presente la incidencia en este proceso de las relaciones y conflictos de poder entre estos distintos grupos. En cierto

95 Augustinus, Epist. 57, 2, ed. GoldBacher 1898, 215-216. Sobre Celer, Mandouze 1982, 202-203, Celer 1.

96 Cf. Athanassiadi 2010, 99.

97 BRown 1971, 100-101: "seen in this way, the victory of Christianity in Late Roman society was not the victory of the One God over the many: it was the victory of men over the institution of their past ... Not just the one God. One God and his man." 
modo, las leyes antipaganas de los emperadores de la dinastía teodosiana, pese a su retórica absolutista, no hacían sino proclamar cuál sería el posicionamiento de la autoridad imperial en el supuesto de conflictos locales entre los cristianos y los paganos: la ley estaba ahí, y correspondía a las instancias locales de poder servirse de ella para excluir a los cultos paganos del espacio público. ${ }^{98}$ En no pocos núcleos urbanos, los obispos habían alcanzado el poder y la capacidad de influencia social y política suficientes para ejecutar estas leyes (la relación de fuerzas paganos / cristianos era favorable al obispo Teófilo en la Alejandría que vio la destrucción del Serapeion, pero no, por ejemplo, a Porfirio en la Gaza de principios del siglo V). En las zonas rurales del Imperio, sin embargo, eran otros patronos, los grandes domini, los únicos detentores de la autoridad necesaria para constituirse en exsecutores de las leyes contra la disidencia religiosa en el Imperio teodosiano. Si estos domini eran cristianos -pues no debemos olvidar que a lo largo del siglo IV se constata todavía, en Hispania por ejemplo, la edificación de templos paganos vinculados a uillae y construidos por iniciativa de los grandes propietarios rurales- ${ }^{99}$ su actitud respecto a las prácticas paganas de sus dependientes podía ir de la total indiferencia denunciada por Máximo de Turín a un activo compromiso en su eliminación, como la del dominus cristiano que retrata Prudencio, fiel exsecutor de la legislación antipagana de Teodosio. Desde el último cuarto del siglo IV, la expansión del ideal ascético cristiano entre amplios sectores de la aristocracia del Imperio y el fenómeno de los secessus in uillam -en parte promovido por un más o menos generalizado sentimiento de la imposibilidad de vivir plenamente el Evangelio en los ambientes urbanos- significó sin duda un impulso a la cristianización "vertical" - de patronus a dependientes- de las zonas rurales. Pero este fenómeno dio a su vez lugar a la aparición de tensiones entre la jerarquía eclesiástica, el centro de cuyo poder era la ciudad, y estos aristócratas cuyas prácticas religiosas parecían querer sustraerse a la fiscalización de la iglesia institucional. Si bien es cierto que los autónomos dominios rurales fueron en efecto bastiones de grupos cristianos abiertamente escindidos y enfrentados a la ortodoxia legal del Imperio teodosiano, no lo es menos que la jerarquía eclesiástica recurrió en algunos casos al expediente de la acusación de heterodoxia religiosa para tratar de someter a su control formas de experiencia del cristianismo que, adoptando como escenario privilegiado el campo, parecían amenazar su liderazgo exclusivo de la comunidad cristiana. Recuérdese que en la Italia Suburbicaria de finales del siglo VI los pontífices romanos llegaron a prohibir la construcción de baptisterios en los oratorios privados de las grandes propiedades rurales. Ejemplo elocuente de la incidencia de las relaciones y tensiones de poder en la cristianización del campo y en el complejo dialogismo ortodoxia / heterodoxia religiosa en el Imperio cristiano.

\footnotetext{
98 De acuerdo con Teodoreto de Ciro, por ejemplo, el obispo Marcelo de Apamea habría sido el primero

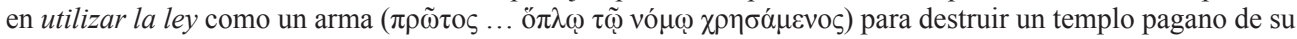
ciudad (cf. Theodoretus Cyr., Hist. ecc. 5, 21, 5, ed. PARMENTIER - Hansen 199833, 318).

99 Casos de Milreu, São Cucufate, Torre de Palma, Quinta do Marim o Carranque, cf. Chavarría 2006, 208.
} 


\section{BIBLIOGRAFÍA}

Athanassiadi, P. (2010): Vers la pensée unique. La montée de l'intolérance dans l'Antiquité tardive, París.

Ballerini, P. - Ballerini, G. (1846): Sancti Leonis Magni Romani pontificis opera omnia, París (reimp. PL 54).

Bartelink, J. M. (1971): Callinicos. Vie d'Hypatios, París (SCh 177).

BIDEZ, J.

(1972): L'empereur Julien. Lettres et fragments, París (CUF).

$\left(1995^{2}\right)$ : Sozomenus Kirchengeschichte, Berlín (GCS NF, 4).

Bowes, K. (2001): "Nec sedere in uillam. Villa-Churches, Rural Piety, and the Priscillianist Controversy", [en] T. S. Burns - J. W. Eadie (eds.), Urban Centers and Rural Contexts in Late Antiquity, Michigan, 323-348.

Brown, P.

(1971): "The Rise and Function of the Holy Man in Late Antiquity", JRS 61, 80-101.

(1998): Pouvoir et persuasion dans l'Antiquité tardive. Vers un Empire chrétien, París (ed. princeps, inglés, 1992).

BuenaCASA, C. (2004): "La creación del patrimonio eclesiástico de las iglesias norteafricanas en época romana (ss. II-V): renovación de la visión tradicional”, $A \& C$ 21, 493-509.

Burgess, R. W. (1993): The Chronicle of Hydatius and the Consularia Constantinopolitana. Two Contemporary Accounts of the Final Years of the Roman Empire, Oxford.

Canivet, P. (1977-1979): Théodoret de Cyr. Histoire des moines de Syrie, París (SCh 234 y 257).

ChavarríA, A. (2006): “Aristocracias tardoantiguas y cristianización del territorio (ss. IV-V): ¿otro mito historiográfico?”, RAC 82, 201-230.

Chavasse, A. (1973): Sancti Leonis Magni Romani Pontificis tractatus septem et nonaginta, Turnhout (CCSL 138 y 138A).

Chuvin, P. (20093): Chronique des derniers païens, París.

Clark, E. G. (2001): "Pastoral Care: Town and Country in Late-Antique Preaching”, [en] T. S. Burns - J. W. Eadie (eds.), Urban Centers and Rural Contexts in Late Antiquity, Michigan, 265-284.

Codou, Y. - Colin, M.-G. - Le Nézet-Célestin, M. (2007): “La christianisation des campagnes (IVe-VIIIe s.)", Gallia 64, 57-83.

Coppieters't wallant, B. - De Coninck, L. - Demeulenaere, R. (2008): Augustinus. Sermones de nouo testamento (51-70A), Turnhout (CCSL $41 \mathrm{Aa})$.

De ClercQ, C. (1963): Concilia Galliae a. 511-695, Turnhout (CCSL 148A).

Dekkers, E. (1954): Tertullianus. Opera I, Turnhout (CCSL 1).

Dekkers, E. - Fraipont, J. (1956): Augustinus. Enarrationes in Psalmos I-L, Turnhout (CCSL 38).

Delmaire, R. (2005): Les lois religieuses des empereurs romains de Constantin à Théodose II. v. i. Code Théodosien XVI, París (SCh 497). 
Destephen, S. (2010): “La christianisation de l'Asie Mineure jusqu'à Constantin: le témoignage de l'épigraphie", [en] H. Inglebert - S. Destephen - B. Dumézil (eds.), Le problème de la christianisation du monde antique, París, 159-194.

Dombart, B. - Kalb, A. (1955): Augustinus. De ciuitate Dei, Turnhout (CCSL 47-48).

DumÉzil, B. (2005): Les racines chrétiennes de l'Europe. Conversion et liberté dans les royaumes barbares, Ve-VIIIe siècle, París.

Escribano, M ${ }^{a}$ V. (2002): "La disputa priscilianista", [en] R. Teja (ed.), La Hispania del siglo IV. Administración, economía, sociedad, cristianización, Bari, 205-230.

Fontaine, J.

(1967): Sulpice Sévère. Vie de saint Martin, t. I, París (SCh 133).

(1968): Vie de saint Martin, t. II, París (SCh 134).

(1969): Vie de saint Martin, t. III, París (SCh 135).

(1972): "Valeurs antiques et valeurs chrétiennes dans la spiritualité des grands propriétaires terriens à la fin du IVe siècle occidental", [en] J. Fontaine - Ch. Kannengieser (eds.), Epektasis. Mélanges patristiques offerts au cardinal Jean Daniélou, París, 571-595.

(1976): "Hagiographie et politique, de Sulpice Sévère à Venance Fortunat", Revue d'histoire de l'Église de France 62, 113-140.

(2006): Sulpice Sévère. Gallus. Dialogues sur les "vertus” de Saint Martin, París (SCh $510)$.

Frend, W. H. C. (1979): “Town and Countryside in Early Christianity”, [en] D. Baker (ed.), The Church in Town and Countryside (=Studies in Church History 16), Oxford, 25-42.

Giordano, O. (1983): Religiosidad popular en la Alta edad media, Madrid (ed. princeps, italiano, 1979).

Goldbacher, A. (1898): S. Aurelii Augustini Hipponiensis episcopi epistulae. Pars II, Praga - Viena - Leipzig (CSEL 34, 2).

Grégoire, H. - Kugener, M.-A. (1930): Marc le Diacre. Vie de Porphyre évêque de Gaza, París (Collection Byzantine).

Halm, K. (1866): Sulpicius Seuerus. Opera, Viena (CSEL 1).

HANSEN, G. CH. (1995): Sokrates Kirchengeschichte, Berlín (GCS NF, 1).

Hartel, G. DE (1999): Paulinus Nolanus. Epistulae (editio altera supplementis aucta), Viena (CSEL 29).

Krueger, P. (1929 $\left.{ }^{10}\right)$ : Corpus Iuris Ciuilis, II: Codex Iustinianus, Berlín.

Lagarrigue, G. (1975): Salvien de Marseille. Euvres, t. II. Du gouvernement de Dieu, París (SCh 220).

Lavarenne, M. (1948): Prudence. Psychomachie. Contre Symmache, París (CUF).

Leone, A. (2006): “Clero, proprietà, cristianizzazione delle campagne nel nord Africa tardoantico", AntTard 14, 95-104.

Leppin, H. (2008): Teodosio, Barcelona, 2008 (ed. princeps, alemán, 2003).

Lizzi, R. (2010): "L'église, les domini, les païens rustici: Quelques stratégies pour la christianisation de l'Occident (IVe-VIe siècle)", [en] H. Inglebert - S. Destephen - B. Dumézil (eds.), Le problème de la christianisation du monde antique, París, 77-113. 
MacMullen, R.

(1989): “The preacher's audience (A. D. 350-400)", JThS 40, 503-511.

(2004): Christianisme et paganisme du IV au VIII siècle, París (ed. princeps, inglés, 1996).

Maier, H. O. (1996): "Manichee!: Leo the Great and the Orthodox Panopticon", JECS 4, 441-460.

Mandouze, A. (1982): Prosopographie chrétienne du Bas-Empire I, Afrique (303-533), París.

Manselli, R. (1982): "Resistenze dei culti antichi nella pratica religiosa dei laici nelle campagne", [en] Cristianizzazione ed organizzazione ecclesiastica delle campagne nell'alto Medioevo: espansione e resistenze. XXVIII Settimana di studio del Centro italiano di studi sull'alto Medioevo, vol. I, Spoleto, 57-108.

Martínez, G. - RodríGuez, F. (1984): La colección canónica hispana, IV, Madrid.

Mommsen, Th.

(1892): MGH aa 9, Chronica minora 1, Berlín.

(1908): Eusebius Werke, II. Die Kirchengeschichte, 2, Leipzig (GCS).

Mommsen, Th. - Meyer, P. M. (1905): Theodosiani libri xvi cum constitutionibus Sirmondianis et leges Nouellae ad Theodosianum pertinentes, I/2: Codex Theodosianus; II/2: Leges Nouellae ad Theodosianum pertinentes, Berlín.

Munier, C. (1963): Concilia Galliae a. 314-506, Turnhout (CCSL 148).

Mutzenbecher, A. (1962): Maximus Taurinensis. Sermonum collectio antiqua nonnullis sermonibus extrauagantibus adiectis, Turnhout (CCSL 23).

Opitz, H.-G. (1938-1940): Athanasius Werke, 2, 1, Berlín - Leipzig.

Parmentier, L. - Hansen, G. C. (19983): Theodoret Kirchengeschichte, Berlín (GCS NF, 4).

Perrin, M.-Y. (2010): “Creuit hypocrisis. Limites d'adhésion au christianisme dans l'Antiquité tardive: entre histoire et historiographie", [en] H. Inglebert - S. Destephen - B. Dumézil (eds.), Le problème de la christianisation du monde antique, París, 47-62.

Petschenig, M. (1909): Augustinus. Contra litteras Petiliani. Epistula ad catholicos de secta Donatistarum. Contra Cresconium grammaticum et Donatistam, Viena - Leipzig (CSEL 52).

Piay Augusto, D. (2006): “Acercamiento prosopográfico al priscilianismo”, $A \& C r$ 23, 2006, 601-625.

Pietri, Ch. (1989): "Saints et démons: l'héritage de l'hagiographie antique", [en] Santi e demoni nell'alto Medioevo occidentale [secoli V-XI]. XXXVI Settimana di studio del Centro italiano di studi sull'alto Medioevo, 7-13 aprile 1988, vol. I, Spoleto, 17-90.

PieTRI, L.

(2002): "Évergétisme chrétien et fondations privées dans l'Italie de l'Antiquité tardive", [en] J.-M. Carrié - R. Lizzi (eds.), Humana sapit. Études d'Antiquité tardive offertes à Lellia Cracco Ruggini, Turnhout, 253-263.

(2005): "Les oratoria in agro proprio dans la Gaule de l'Antiquité tardive: un aspect des rapports entre potentes et évêques", [en] Ch. Délaplace (ed.), Aux origines de la paroisse rurale en Gaule méridionale, IVe-VIe siècles. Actes du colloque international, 21-23 mars 2003, París, 235-242.

Richardson, E. C. (1896): Hieronymus, Liber de uiris inlustribus - Gennadius, Liber de uiris inlustribus, Leipzig (Texte und Untersuchungen 14, 1a). 
Rodríguez, F. (1981): “Concilio I de Zaragoza. Texto crítico”, [en] G. Fatás (dir.), I Concilio Caesaraugustano. MDC Aniversario, Zaragoza, 15-25.

SAn Bernardino, J. (1997): "Exilio y muerte de un heterodoxo en la tardorromanidad: en torno al caso de Pascentius en Lusitania", [en] R. Teja - C. Pérez (eds.), Actas del Congreso Internacional La Hispania de Teodosio, vol. 1, Salamanca, 217-231.

TAngl, M. (1916): S. Bonifatii et Lulli Epistolae, Berlín (MGH epist. select. I).

Treadgold, W. (1994): “Taking Sources on their Own Terms and on Ours: Peter Brown's Late Antiquity", AntTard 2, 153-159.

Vilella, J. (1997): “Un obispo-pastor de época teodosiana: Prisciliano", [en] Vescovi e pastori in epoca teodosiana. XXV Incontro di studiosi dell'antichità cristiana (=Studia Ephemeridis Augustinianum 58/2), Roma, 503-530.

Villegas Marín, R. (2004): "Vnanimitatem diligite: la persecución del maniqueísmo durante el pontificado de León I (440-461)", Polis 16, 213-244.

(2010): Pseudo-Próspero de Aquitania. Sobre la providencia de Dios. Introducción, texto latino revisado, traducción y comentario, Barcelona.

Weber, M. (1996): Sociologie des religions, París.

Winkelmann, F. (1975): Eusebius Werke I, 1. Über das Leben des Kaisers Konstantin, Berlín, $(G C S)$. 